\title{
Bridging State and Nonprofit: Differentiated Embeddedness of Chinese Political Elites in Charitable Foundations
}

\author{
$\mathrm{Ji} \mathrm{Ma}{ }^{1}$ \\ Accepted: 11 March 2022 \\ (C) The Author(s) 2022
}

\begin{abstract}
How are political elites embedded in both civil and political domains? I studied 246 Chinese political elites who also served on nonprofit foundations' boards from 2011 to 2015 and conceptualized a framework to understand the state-nonprofit relationship before 2015. The political elites can build horizontal connections with foundations, helping the party-state reach nonprofit actors. They can also build vertical connections with political groups, helping foundations access political resources. The dual-role elites' connectedness with foundations and in the polity varies by their primary positions in the political system. Effective communication between the state and nonprofit actors requires elites to have strong connections in both the civil and political domains, but the situation in China is far from ideal-those embedded in foundations are disconnected from the polity, and those connected in the polity are marginalized in foundations.
\end{abstract}

Keywords Chinese political elites $\cdot$ Nonprofit sector $\cdot$ Civil society $\cdot$ Political networks · Nonprofit foundation $\cdot$ Chinese Communist Party $\cdot$ Chinese Youth League

\section{Introduction}

The relationship between the party-state and nonprofits in China has been of interest to scholars, practitioners, and politicians for a few decades because of the expectation and fear that a burgeoning nonprofit sector may bring multiparty democracy to the authoritarian regime. A rich body of scholarship has been crafted from different macro perspectives; however, we are still in dire need of a framework to understand how the party-state and nonprofit actors interplay at the meso and micro levels.

Ji Ma

maji@austin.utexas.edu

1 LBJ School of Public Affairs RGK Center for Philanthropy and Community Service, The University of Texas at Austin, 2315 Red River St, Austin, TX 78712, USA 
Scholars have introduced numerous theoretical lenses to better understand the state-nonprofit relationship. The initial attempt started in the early 1990s, when scholars and policymakers primarily used a neo-Tocquevillian perspective and theorized the relationship as conflicting (e.g., [9, 44]). The second wave started in the mid-2000s, when scholars and policymakers tried to theorize the relationship as being contingent and applied a lens of corporatism. Studies of this stream, for example, those on "graduated control" [31], "contingent symbiosis" [65], and "consultative authoritarianism" [67], framed nonprofit actors as the service arms of the state, leaving room for these organizations to grow. However, their survival is still contingent upon their focuses on nonpolitically sensitive areas. The third wave started in the late 2010s, when the relationship was theorized as being networked. Scholarship of this wave began to emphasize the active roles of nonprofit actors and the mutual embeddedness between the civil and political domains (e.g., [41, 68]). A growing number of scholars have started to emphasize the blurring boundary between the party-state and nonprofit sector (e.g., [16, 21, 62, 64, 72, 79]).

This study follows this research trend and advances our understanding of the mutual embeddedness between political and civil actors in China. By examining 246 political elites who also served on nonprofit foundations' boards from 2011 to 2015, I analyzed their profiles and networks and found that the dual-role elites who are popular in the nonprofit sector are marginalized in the party-state, and vice versa. In order to make the state-in-society strategy work [46], political elites need to have strong connections in both the civil and political domains. But the situation in China is far from ideal-those embedded in foundations are disconnected from the polity, and those connected in the polity are marginalized in foundations. We need to be cautious about generalizing the findings because this study only covers foundations and there are other channels between the party-state and nonprofit sector. However, as one of the first studies theorizing a framework at the meso and micro levels, this paper provides an essential baseline and can serve as a stimulus for future research.

\section{Research Framework: Differentiated Embeddedness in a Multilayer-Network}

The dual-role elites' double-embeddedness can be conceptualized through a multilayer-network perspective. From this perspective, an individual's purpose is a function of that person's embeddedness in a specific domain, and one individual can have multiple purposes that are defined by the different domains in which they are embedded [51, 1469]. As Fig. 1 illustrates, the same political elites can be embedded in both the civil and political spaces.

The multilayer-network figure also presents two important notions in the literature on the state-nonprofit relationship in China: horizontal and vertical connections (e.g., [39, 58]). A horizontal connection primarily considers how nonprofits are mutually connected (e.g., [22]), and a vertical connection measures these actors' access to political resources. The political elites who are embedded in both civil and political arenas are crucial-they can 


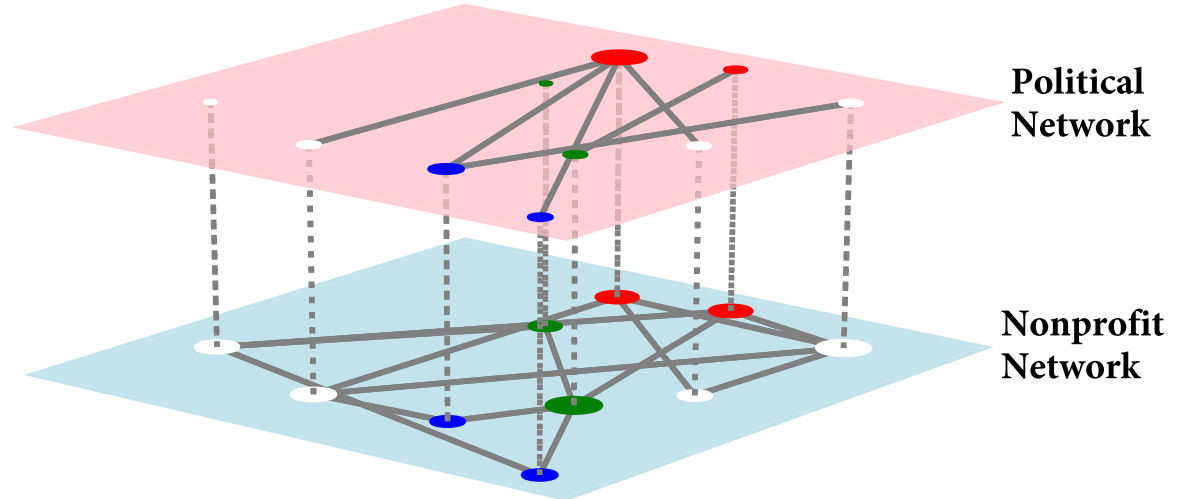

Fig. 1 Bridging civil and political spaces: A multilayer-network perspective. Notes: The image is only for illustration and does not reflect real observations. Non-political actors in the nonprofit network are hidden for visual clarity. Nodes in the same color indicate political elites from the same political organizations. For example, red nodes are all political elites from the Chinese Communist Party. Nodes in the same positions but in different networks represent the same individuals. Node size represents the number of direct connections of a node in that given network

Table 1 Theoretical framework: Differentiated embeddedness of Chinese political elites

\begin{tabular}{|c|c|c|}
\hline & $\begin{array}{l}\text { Nonprofit embeddedness (horizontal con- } \\
\text { nection) }\end{array}$ & $\begin{array}{l}\text { Political embeddedness (vertical con- } \\
\text { nection) }\end{array}$ \\
\hline \multicolumn{3}{|c|}{ Embeddedness of political elites } \\
\hline Strong & State agents for accessing civic resources & Access points to the party-sate \\
\hline Weak & Weak state agents in nonprofits & $\begin{array}{l}\text { Ineffective access points to political } \\
\text { resources }\end{array}$ \\
\hline
\end{tabular}

build horizontal connections with nonprofit groups, and they can also build vertical connections with the party-state. In a nutshell, they are unique players bridging civil and political spaces.

Combining the multilayer-network perspective and the two notions of connection, Table 1 illustrates the theoretical framework. The dual-role elites can be grouped into four categories according to their embeddedness. 1) Those who have strong connections in nonprofits are excellent state agents when it comes to reaching nonprofit actors. 2) Those who have strong connections in the polity can serve as access points to the party-state. 3) Those who are less connected in nonprofits are weak state agents. And 4) those who are less connected in the polity are ineffective access points to political resources. The sections below briefly review these elites' roles in the civil and political domains.

\section{Political Elites in the Nonprofit Sector: Access Points to Political Resources}

Chinese political elites have been active players in the nonprofit sector since the founding of the socialist state. In the 1950s, numerous mass organizations were 
created by the state, and they are still quasi-government units today. The party-state also created the first nonprofit foundations in the early 1980s, and most of their staff in the following two decades were government employees. Even in the late 1990s, the majority of Chinese nonprofits were staffed by government officials serving as employees and political elites serving as board members [24, 232-233].

The regulations on how to register a nonprofit in China all employed an important strategy for the state to monitor the nonprofit sector-the "dual registration" system. ${ }^{1}$ According to these regulations, a nonprofit was required to 1) have a government department serving as its "supervisory sponsor" and 2) register with the departments of civil affairs at different levels in the party-state. As a result, nonprofits in China differ from their counterparts in Western democracies: they have limited autonomy and are closely monitored or even directly established by the state [43]. These nonprofits, particularly those engaging in politically sensitive activities, must prudently manage their relationships with the state to achieve a "contingent symbiosis" [65].

Despite these operational constraints, the number of nonprofits in China has increased substantially since the 1989 Tiananmen Square protests, and the interaction between these organizations and the party-state is bidirectional. Nonprofits in China can have considerable policy influence through their connection to the state $[56,210]$; [45], and the state also relies on them as an indirect tool of social control [67]. In short, the party-state actors and nonprofits are mutually embedded.

For example, [68] found that nonprofits exploited their governmental supervisors as access points to the policymaking process, which they would not have been able to access otherwise, and formed policy networks with these policymakers that resemble those in Western democracies. Another study on Chinese nonprofit foundations found that, as a dominant power in the Chinese nonprofit sector, these organizations were able to form a decentralized organizational network through board interlocking relationships. Despite the widespread appearance of government officials on foundations' boards, Chinese nonprofits were able to cluster into several autonomous elite groups and form a multipolar structure that resembles what is found in liberal societies [41]. Moreover, [39] discovered that grassroots nonprofit actors formed "horizontal connections" with each other and that they also forged "vertical connections" with the state through retired government officials.

The literature has singled out the fact that the party-state relies on political elites to monitor the activities of nonprofits. But more importantly, nonprofits can also exploit these elites to reach the party-state. However, scholars have rarely investigated how exactly these dual-role politicians function.

\footnotetext{
1 Nonprofits in China can register in different legal forms that are administered by different regulations. For example, the Regulations on the Registration and Management of Social Organizations introduced in 1998 and the Regulations on the Registration and Management of Foundations introduced in 2004 all employ the "dual registration" system.
} 


\section{Political Elites in the Party-State: Unification and the Fractured Polity}

\section{Unifying politics and administration}

Democratic regimes are characterized by a separation of power $[37,38$, 55], but China's post-Mao era is experiencing the opposite. In the 1980s, political elites in China had already realized that the party-government relationship was the major challenge to reforming the political structure, but later legislation made no progress in separating the cadre and civil servants because such separation would fundamentally challenge the Chinese Communist Party's (CCP's) hegemony [66]. The enactment of the Law on Public Servants in 2005 formally institutionalized the combination of politics and administration by recategorizing public servant positions as "leading" or "non-leading" [10, 389].

As Table S4 in the Appendix presents, Chinese political leaders in "leading positions" are ranked in ten categories, from the lowest rank of "Section/ Township Deputy" (xiangkeji fuzhi) to the highest rank of "State Leader" (guojiaji zhengzhi). These ranks also correspond to geographic levels, with the township level being the lowest and the state or central level being the highest [53, Article 16]; [10, 393]. Leadership changes follow the "one-level-down" and "party control" principles, in that the party committees at a lower level prescreen the proposals to be submitted to the party organizations at a higher level for decision-making purposes [10, 392]. For example, a party committee at the bureau/department level will review a list of candidates before submitting their proposal to the party committee at the province/ministry level for decision-making.

The number of cadres at different levels comprise a pyramid structure. In 1998, there were approximately 545,000 leading cadres who were ranked at the county level and above (i.e., xianchuji and above). Among them, over 500,000 were at the county level or below, 34,000 were at the bureau or municipal level, 2,500 were at the ministerial or provincial level, and less than 1,000 were at the national level $[6,392]$. Although leaders at the provincial level are not large in number, they are important brokers between local and national political elites [56, 144].

\section{A Fractured Political System}

Although CCP members hold more than $96 \%$ of the leading positions [6, 391], they serve in different political and bureaucratic institutions. Thus, these political elites may represent the interests of different departments that do not necessarily hold views consistent with those of the central leaders.

Such misalignment is real and emergent-the political elites are far from being a unified group. For example, the leaders of state-owned enterprises form a powerful group of corporate elites who are highly independent from government agencies [5]. Meanwhile, the People's Consultative Council, which comprises non-CCP elites from diverse social and economic professions, plays an important role in political 
participation and consultation [23]; [78, 689]. Furthermore, as the CCP's primary youth organization, the Chinese Youth League (CYL) prepares youths to be the "assistants and reserve army" for the party. However, having this separate group may also be supporting the rise of the "CYL Clique" (tuanpai) within the party [32, 159-162]. Finally, intellectuals have opened up a robust public sphere for political debate $[18,13]$. Most, if not all, of these individuals are CCP members, but they serve in various institutions and are driven by different interests.

To handle the potential threat of a fractured polity, the CCP's central leaders began to bypass political and bureaucratic institutions and strengthen the party's direct governance at all levels during Xi Jinping's presidency [20]. In November 2018, the Central Committee of the CCP released the Regulations on the Operation of the Party Branches, which required all social, economic, and military "units" to establish CCP branches, and a unit was defined as having three or more CCP members, regardless of its registration status (e.g., as a formally incorporated cooperative company, private company, publicly listed company, or even a temporary working team; [76]). Although such a requirement has long existed since the 1990s, it became unprecedentedly compelling during Xi's presidency [48, 2]. Besides establishing the CCP branches, the $\mathrm{Xi}$ administration has invested more effort in advancing the party's direct control. In 2013, only two regulations of this sort were made. The number was tripled in 2015. Then in 2018 alone, thirteen regulations were announced, followed by twenty-two in $2019 .^{2}$

\section{Research Questions}

Based on the theoretical framing and the analysis of the elites' roles, I am motivated to explore how these dual-role elites are embedded in the civil and political domains. Specifically, I develop this study from three perspectives.

1. What are the characteristics of the dual-role elites? Answering this question involves examining the elites' demographics, their cadre ranks and positions, and how these characteristics change over time.

2. What are the profiles of the social and institutional networks? This switches our analysis from studying the individuals to describing the networks in which these individuals are embedded. Answering this question discloses the structures of these networks.

3. What are the patterns of embeddedness? Finally, I analyze the patterns of interactions between these elites. The analysis helps us group the dual-role elites as Table 1 theorizes, creating a framework and stimulus for understanding the differentiated embeddedness of political elites in the nonprofit sector.

\footnotetext{
${ }^{2}$ Source: Central Committee Documents (http://www.gov.cn/zhengce/wenjian/zhongyang.htm). Coding criteria: 1) "CCP Central Committee" (zhonggong zhongyang) is in the title, 2) "State Council" (guowuyuan) is not in the title, and 3) double angle quotation marks $(\langle)$ are in the title.
} 


\section{Data and Methods}

\section{Data Sources}

I used two datasets: the Research Infrastructure of Chinese Foundations (RICF; [42]) for charitable foundations and the Chinese Political Elite Database (CPED; [29]) for political elites. The online appendixes have more details on data preprocessing and validation.

Research Infrastructure of Chinese Foundations The RICF provides comprehensive data on Chinese foundations, including their institutional characteristics, financial status, and personnel from 2013 to 2016 . The data descriptor of the RICF contains more technical details on dataset construction and validation [42]. Following this descriptor, I constructed a dataset on foundations from 2010 to 2016. Although each year is different, roughly $30 \%$ of all the foundations are eligible to raise funds publicly, ${ }^{3}$ the board size is $11.72(S D=6.44)$ people on average, and there are about 140 political elites embedded in the foundation network each year. Tables S1 and S2 in the Appendix have more details about the foundations.

Chinese Political Elite Database The CPED is a biographical database that contains the demographic and career information of over 4,000 Chinese political leaders who belong to one of the following groups: 1) "all city secretaries, mayors, and members of provincial standing committee[s] between 2000 and 2015," 2) "all provincial secretaries and governors between 1995 and 2015," and 3) "all other full and alternate Central Committee members between 1987 and 2012" [29, A-2]. These criteria also serve as the definition of a "political elite" in this paper.

The final linked dataset tracks an elite's foundation membership and political position in a given year. For example, as Fig. S2 in the appendix shows, the political elite CJS was on two foundations' boards (i.e., Foundation ID 250 and 1387) between 2010 and 2015, and he changed his primary position four times during the same time period.

The limitations of the data sources may bias the analysis, and selection bias is the most concerning issue. First, the foundations included are only a part of China's nonprofit sector. Therefore, using foundations as the primary units of analysis may ignore the activities of other nonprofits. However, empirical analysis shows that foundations are the most developed form of and the dominant power in the Chinese nonprofit sector [33]; [41, 293], and they also contribute to our understanding of the state-civil society relationship in authoritarian countries [34, 5]. Second, a substantial number of foundations are created by the government [70, 308]. As a result, the analysis may merely reflect the assignments of the party-state. However, these government-created foundations are not isolated agents; the are instead structurally

\footnotetext{
3 These public-fundraising foundations usually have closer relationship to the state [70].
} 


\section{Affiliational Network}

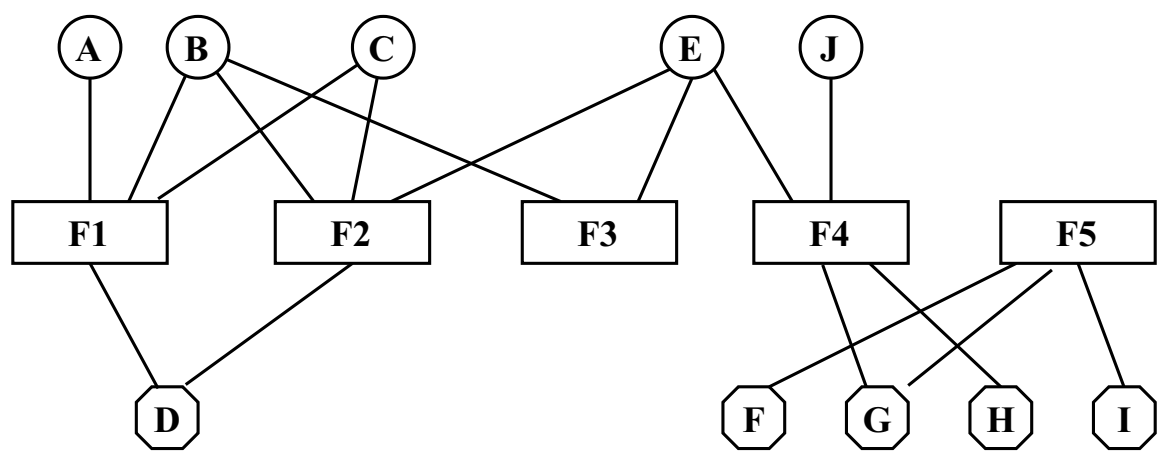

\section{Board Interlocking Network}

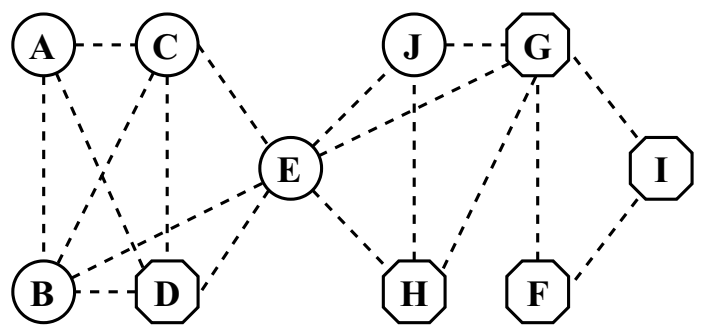

Legend

Nongovernmental actors

Party-state actors

$\square$ Foundations

Board membership

- - - Board interlocking

Fig. 2 Dependent variables: Nonprofit and political embeddedness

connected to other types of foundations [41, 294] and lead the development of the foundation landscape [70, 297]. Third, the CPED may miss cadres at the grassroots level, but the technical details of its construction and validation suggest that the dataset is better than acceptable [29]. Moreover, these grassroots cadres may have limited influence on the foundation landscape in comparison to high-level political elites. In general, we can expect that the biases of the analysis due to data source limitations are unavoidable but better than acceptable.

\section{Variables}

\section{Dependent Variables: Nonprofit and Political Embeddedness}

I used board interlocking relationships between nonprofit foundations to operationalize the dependent variables. In theory, the board interlocking relationship plays a crucial role in organizational governance and strategy. Although controversial in practice because organizational behaviors largely exist outside of boardrooms, the board interlocking relationship has been empirically tested as a valid proxy to study 
the organizational relationships of companies and nonprofits (e.g., [13, 15, 17, 40, 47, 73]).

I constructed two dependent variables to measure a political elite's horizontal and vertical connections: nonprofit embeddedness is operationalized by counting an elite's connections to nongovernmental actors, and political embeddedness is defined as an elite's connections to the party-state actors. Figure 2 illustrates how the two variables are constructed. I first create a bipartite affiliational network using board membership in which there are two types of nodes (i.e., foundation and board member; Subgraph 1 in Fig. 2). Then the bipartite network is converted to a unipartite board interlocking network in which nodes represent board members (Subgraph 2 in Fig. 2). Take node $G$ in the figure for example: its nonprofit embeddedness is 2 (connected to $\mathrm{E}$ and $\mathrm{J}$ ), and its political embeddedness is 3 (connected to $\mathrm{H}, \mathrm{F}$, and I). Meanwhile, individual D's nonprofit embeddedness is 4 and political embeddedness is 0 .

\section{Independent and Control Variables}

The primary independent variable is political position. It is a categorical variable and coded according to an individual's primary position in a given year using the itemized curriculum vitae from the CPED. The variable has ten categories: 1) Chinese Communist Party (CCP; only when individuals directly serve as party officials, e.g., as the secretary of a party committee), 2) Chinese Youth League (CYL), 3) Judiciary, 4) Mass Organization (MO; e.g., the All-China Women's Federation), 5) People's Congress (PC), 6) People's Consultative Council (PCC), 7) State Council, 8) Central state-owned enterprise (CSOE), 9) Local state-owned enterprise (LSOE), and 10) School (e.g., university principals).

There are two caveats in coding these categories. First, the CYL is also a mass organization, but it is coded separately because of its direct affiliational relationship with the CCP (i.e., preparing youths to be the CCP's “assistants and reserve army") and because of the evidence of the CYL Clique [32, 162]. Second, if individuals hold multiple positions simultaneously, I used the position that 1) has a longer track record or 2) has more important roles in policymaking $[4,28,57,80]$.

Control variables in the regression analysis include demographics (i.e., age, gender, education, and cadre rank) to control the influence of individual characteristics. A foundation's average board size is included to control organizational influence because individuals on larger boards can have more connections.

\section{Estimation Strategy}

To understand how political actors in different positions are embedded, the two dependent variables (i.e., nonprofit embeddedness and political embeddedness) are regressed on political position and controls. An ideal analysis should take advantage of the dataset's panel structure, but the analysis of 
data quality (Fig. S1 and Table S2) suggests the within-category variations of political position are small. Therefore, a fixed-effect regression is not appropriate if we use political position as the primary independent variable. Thus, the strategy is to use a pooled ordinary least squares regression to generate initial findings and then to conduct qualitative member checking to explain and confirm the findings-a quasi-"explanatory sequential design" in mixed methods $[12,66]$.

Two limitations may bias the quantitative estimations. First is the presidential preferences. Because President Hu Jintao was the head of the CYL and his presidency has been considered to have ushered in the rise of the CYL clique [32], it is possible that cadres with previous CYL experience were favored during Hu's presidency. Therefore, I considered cadres' previous CYL experience in the robustness check.

Second, using only foundations' board interlocking relationships cannot capture "social ties beyond the boardroom" [2, 37]. The ties formed through other channels, for example, political elites' work relationships and friendships made through private social clubs, can reduce the social distance between elites. However, the dependent variables and regression models cannot consider these interactions. Nevertheless, it is difficult to obtain affiliational data of this sort even in democratic countries where political and social operations are much more transparent. Because individuals who have connections with different social groups are structural holes who bridge heterogeneous information and are more likely to form weak social ties outside of boardrooms [8, 19], I used the Herfindahl index of the types of political connections (i.e., embeddedness diversity) to approximate these social ties. ${ }^{4}$

For the qualitative member checking, I conducted a series of interviews and focus groups following "explanatory sequential design" in mixed methods $[12,66]$. Using the dataset in this study, I identified a list of highly connected political elites in both the civil and political networks. Then I contacted a scholarly network in China and consulted a few scholars associated with several of the most prestigious Chinese universities. Because interviewing political elites in this study would be extremely difficult, if not impossible, these scholars helped me by 1) interviewing several key informants who were colleagues of these political figures and 2) arranging presentations at universities, foundations, and think tanks that were closely associated with these elites. The interviews and focus groups used the theoretical framework (Table 1) as an instrument and primarily focused on three questions: 1) the interviewees' opinions and understanding of the framework, 2) how they would group the political elites, and 3) the reasons for their grouping. Because the informants were selected through snowball sampling,

\footnotetext{
4 The Herfindahl index is calculated as $\sum_{i=1}^{n} s_{i}^{2}$, where $s_{i}$ is the share of all institutional connection $i$, and $n$ is the total types of institutional connections. For example, individual $a$ has four total connections, in which $n=3$ and $\dot{i}_{1}=2, i_{2}=1$, and $i_{3}=1$, the embeddedness diversity of individual $a$ is $\left(\frac{2}{4}\right)^{2}+\left(\frac{1}{4}\right)^{2}+\left(\frac{1}{4}\right)^{21}$.
} 


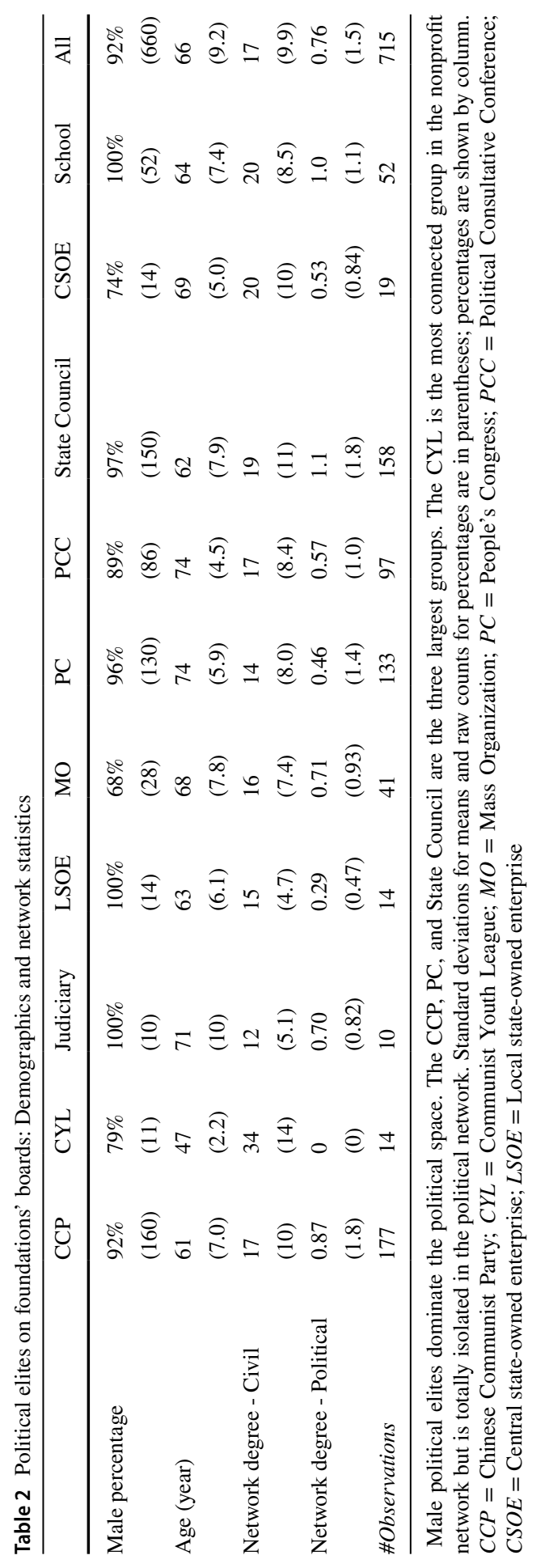




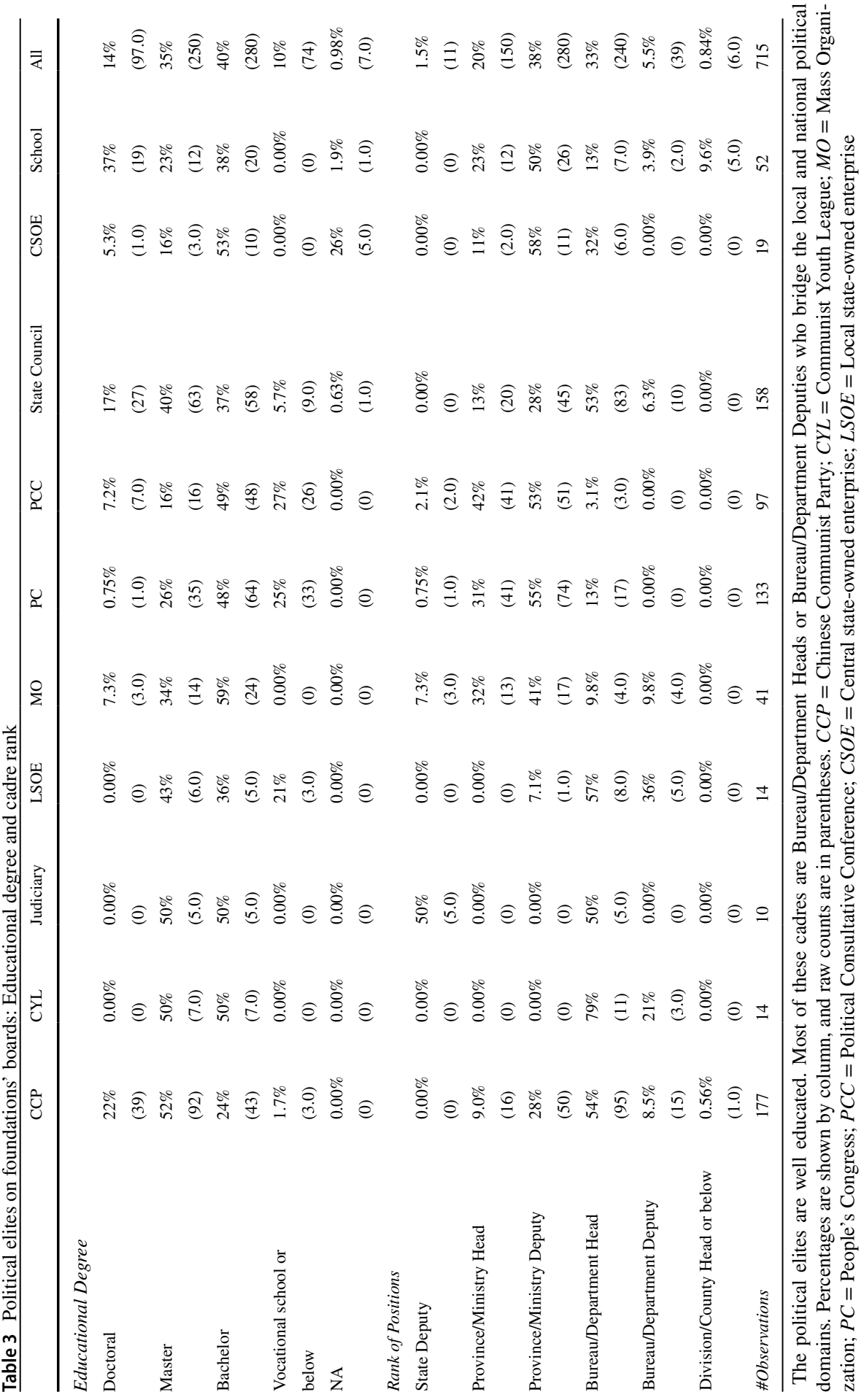


the qualitative fieldwork and analysis focused on process tracing to minimize the influence of selection bias $[3,61]$.

\section{Results}

\section{Profile of the Dual-Role Elites}

Table 2 presents the demographics and network statistics of the political elites who sit on foundation boards. Male leaders dominate the political elites (92\%), and some positions are male only (i.e., leaders of the Judiciary, LSOE, and School). The most gender-diverse positions are found in $\mathrm{MO}$, where females account for $32 \%$ of the political elites. The CYL leaders are the youngest (with a mean age of 47 years) and most connected group in the nonprofit network (being connected to 34 people on average), but none of the CYL leaders have connections with political actors. The CCP, PC, and State Council leaders are dominant in number-each accounts for approximately $20 \%$ of the total observations.

Table 3 presents education and cadre ranking profiles. With respect to educational background, the political elites are a highly educated group: $49 \%$ of all leaders hold a master's degree or above, and $37 \%$ of the School leaders and $22 \%$ of the CCP leaders hold a doctoral degree. Although high-ranking officials may have ways of obtaining advanced degrees without substantial work, these political elites are still a well-educated group.

With respect to the positions' ranks, 33\% are political leaders at the local government level (i.e., Bureau/Department leaders who govern provincial or municipal areas). ${ }^{5}$ Over half of the political elites are at the Province/Ministry levels, where they play important roles in bridging local and national political leaders. This spindle-shaped structure differs significantly from the pyramid structure of the cadre system as a whole $[1,693 ; 6,391]$.

Table 4 presents the positional categories and ranks of the political elites by time. From 2011 to 2015, the CCP, PC, and State Council were the top three political groups that integrated nonprofits. Even in 2013, when $\mathrm{Xi}$ ascended to power, the percentages of positional categories remained largely stable, ${ }^{6}$ and no substantial fluctuation in ranks occurred in the time period observed.

In general, the demographics suggest that the political elites embedded in Chinese foundations are a male-dominated and well-educated group who are focused on bridging local and national interests. Despite the high turnover rate of individuals (Fig. S1), the positional structure of these elites is well institutionalized and stable.

\footnotetext{
5 The CPED indexes a political elite's curriculum vitae by time, and the dataset for this study is panel. Therefore, I am able to capture some grassroots carders. For example, an individual promoted to "Province/Ministry Deputy" in 2015 may be "Bureau/Department Deputy" in 2011.

${ }^{6}$ As CSOE and CYL leaders have disappeared almost entirely, they accounted only for a very small proportion $(<5 \%)$.
} 
Table 4 Political elites on foundations' boards: Position and rank by time

\begin{tabular}{|c|c|c|c|c|c|c|}
\hline & 2011 & 2012 & 2013 & 2014 & 2015 & All \\
\hline \multicolumn{7}{|l|}{ Category of Positions } \\
\hline $\mathrm{CCP}$ & $\begin{array}{l}20 \% \\
(28)\end{array}$ & $\begin{array}{l}28 \% \\
(38)\end{array}$ & $\begin{array}{l}26 \% \\
(39)\end{array}$ & $\begin{array}{l}24 \% \\
(36)\end{array}$ & $\begin{array}{l}26 \% \\
(36)\end{array}$ & $\begin{array}{l}25 \% \\
(180)\end{array}$ \\
\hline CYL & $\begin{array}{l}2.8 \% \\
(4.0)\end{array}$ & $\begin{array}{l}2.9 \% \\
(4.0)\end{array}$ & $\begin{array}{l}2.7 \% \\
(4.0)\end{array}$ & $\begin{array}{l}1.4 \% \\
(2.0)\end{array}$ & $\begin{array}{l}0.00 \% \\
(0)\end{array}$ & $\begin{array}{l}2.0 \% \\
(14)\end{array}$ \\
\hline Judiciary & $\begin{array}{l}1.4 \% \\
(2.0)\end{array}$ & $\begin{array}{l}1.5 \% \\
(2.0)\end{array}$ & $\begin{array}{l}1.3 \% \\
(2.0)\end{array}$ & $\begin{array}{l}1.4 \% \\
(2.0)\end{array}$ & $\begin{array}{l}1.4 \% \\
(2.0)\end{array}$ & $\begin{array}{l}1.4 \% \\
(10)\end{array}$ \\
\hline LSOE & $\begin{array}{l}0.71 \% \\
(1.0)\end{array}$ & $\begin{array}{l}1.5 \% \\
(2.0)\end{array}$ & $\begin{array}{l}2.7 \% \\
(4.0)\end{array}$ & $\begin{array}{l}2.7 \% \\
(4.0)\end{array}$ & $\begin{array}{l}2.2 \% \\
(3.0)\end{array}$ & $\begin{array}{l}2.0 \% \\
(14)\end{array}$ \\
\hline MO & $\begin{array}{l}5.0 \% \\
(7.0)\end{array}$ & $\begin{array}{l}3.6 \% \\
(5.0)\end{array}$ & $\begin{array}{l}4.7 \% \\
(7.0)\end{array}$ & $\begin{array}{l}6.8 \% \\
(10)\end{array}$ & $\begin{array}{l}8.6 \% \\
(12)\end{array}$ & $\begin{array}{l}5.7 \% \\
(41)\end{array}$ \\
\hline $\mathrm{PC}$ & $\begin{array}{l}16 \% \\
(23)\end{array}$ & $\begin{array}{l}17 \% \\
(23)\end{array}$ & $\begin{array}{l}19 \% \\
(29)\end{array}$ & $\begin{array}{l}22 \% \\
(32)\end{array}$ & $\begin{array}{l}19 \% \\
(26)\end{array}$ & $\begin{array}{l}19 \% \\
(130)\end{array}$ \\
\hline PCC & $\begin{array}{l}13 \% \\
(18)\end{array}$ & $\begin{array}{l}13 \% \\
(18)\end{array}$ & $\begin{array}{l}14 \% \\
(21)\end{array}$ & $\begin{array}{l}14 \% \\
(21)\end{array}$ & $\begin{array}{l}14 \% \\
(19)\end{array}$ & $\begin{array}{l}14 \% \\
(97)\end{array}$ \\
\hline State Council & $\begin{array}{l}29 \% \\
(41)\end{array}$ & $\begin{array}{l}22 \% \\
(31)\end{array}$ & $\begin{array}{l}21 \% \\
(31)\end{array}$ & $\begin{array}{l}19 \% \\
(28)\end{array}$ & $\begin{array}{l}19 \% \\
(27)\end{array}$ & $\begin{array}{l}22 \% \\
(160)\end{array}$ \\
\hline CSOE & $\begin{array}{l}5.0 \% \\
(7.0)\end{array}$ & $\begin{array}{l}3.6 \% \\
(5.0)\end{array}$ & $\begin{array}{l}2.7 \% \\
(4.0)\end{array}$ & $\begin{array}{l}1.4 \% \\
(2.0)\end{array}$ & $\begin{array}{l}0.72 \% \\
(1.0)\end{array}$ & $\begin{array}{l}2.7 \% \\
(19)\end{array}$ \\
\hline School & $\begin{array}{l}7.1 \% \\
(10)\end{array}$ & $\begin{array}{l}7.3 \% \\
(10)\end{array}$ & $\begin{array}{l}6.0 \% \\
(9.0)\end{array}$ & $\begin{array}{l}6.8 \% \\
(10)\end{array}$ & $\begin{array}{l}9.4 \% \\
(13)\end{array}$ & $\begin{array}{l}7.3 \% \\
(52)\end{array}$ \\
\hline \multicolumn{7}{|l|}{ Rank of Positions } \\
\hline State Deputy & $\begin{array}{l}1.4 \% \\
(2.0)\end{array}$ & $\begin{array}{l}0.72 \% \\
(1.0)\end{array}$ & $\begin{array}{l}1.3 \% \\
(2.0)\end{array}$ & $\begin{array}{l}2.0 \% \\
(3.0)\end{array}$ & $\begin{array}{l}2.2 \% \\
(3.0)\end{array}$ & $\begin{array}{l}1.5 \% \\
(11)\end{array}$ \\
\hline Province/Ministry Head & $\begin{array}{l}18 \% \\
(26)\end{array}$ & $\begin{array}{l}17 \% \\
(24)\end{array}$ & $\begin{array}{l}21 \% \\
(32)\end{array}$ & $\begin{array}{l}23 \% \\
(34)\end{array}$ & $\begin{array}{l}21 \% \\
(29)\end{array}$ & $\begin{array}{l}20 \% \\
(150)\end{array}$ \\
\hline Province/Ministry Deputy & $\begin{array}{l}35 \% \\
(50)\end{array}$ & $\begin{array}{l}39 \% \\
(54)\end{array}$ & $\begin{array}{l}37 \% \\
(55)\end{array}$ & $\begin{array}{l}41 \% \\
(60)\end{array}$ & $\begin{array}{l}40 \% \\
(56)\end{array}$ & $\begin{array}{l}38 \% \\
(280)\end{array}$ \\
\hline Bureau/Department Head & $\begin{array}{l}35 \% \\
(50)\end{array}$ & $\begin{array}{l}36 \% \\
(49)\end{array}$ & $\begin{array}{l}33 \% \\
(50)\end{array}$ & $\begin{array}{l}31 \% \\
(45)\end{array}$ & $\begin{array}{l}32 \% \\
(45)\end{array}$ & $\begin{array}{l}33 \% \\
(240)\end{array}$ \\
\hline Bureau/Department Deputy & $\begin{array}{l}7.8 \% \\
(11)\end{array}$ & $\begin{array}{l}6.5 \% \\
(9.0)\end{array}$ & $\begin{array}{l}6.7 \% \\
(10)\end{array}$ & $\begin{array}{l}2.7 \% \\
(4.0)\end{array}$ & $\begin{array}{l}3.6 \% \\
(5.0)\end{array}$ & $\begin{array}{l}5.5 \% \\
(39)\end{array}$ \\
\hline Division/County Head and below & $\begin{array}{l}1.4 \% \\
(2.0)\end{array}$ & $\begin{array}{l}0.72 \% \\
(1.0)\end{array}$ & $\begin{array}{l}0.67 \% \\
(1.0)\end{array}$ & $\begin{array}{l}0.68 \% \\
(1.0)\end{array}$ & $\begin{array}{l}0.72 \% \\
(1.0)\end{array}$ & $\begin{array}{l}0.84 \% \\
(6.0)\end{array}$ \\
\hline \#Observations & 141 & 138 & 150 & 147 & 139 & 715 \\
\hline
\end{tabular}

The compositions of category and rank are quite stable over time. Percentages are shown by column, and raw counts are in parentheses. $C C P=$ Chinese Communist Party; $C Y L=$ Communist Youth League; $M O=$ Mass Organization; $P C=$ People's Congress; $P C C=$ Political Consultative Conference; $C S O E=$ Central state-owned enterprise; $L S O E=$ Local state-owned enterprise 


\section{Social and Institutional Networks Created Through Foundations}

Figure 3 shows the political elites in nonprofit and political networks from 2011 to 2015. Contrary to many beliefs about authoritarianism that assume a dominant ruling party, the actors in the networks are diverse. This finding is consistent with prior empirical studies, which have found pluralistic and multipolar structures in policy and nonprofit networks [41, 68]. The connections between different formal institutions (the bold edges in Fig. 3) are widespread (>70\% for all years; Fig. 4). Put together, the political elites embedded in the nonprofit sector form a well-educated and pluralistic group that connects local and national interests.

The networks presented in Fig. 3 also suggest a crucial structural change: the formation and dissolution of political cliques along with presidential changes. I used transitivity, an important structural feature in social networks, to measure such structural change [25, 26]. Transitivity presumes that if $a$ chooses $b$ as an ally, and $b$ chooses $c$ as an ally, then $a$ will also choose $c$ as an ally. As Fig. 3 shows, there were dense cliques (or "triangles" in social network analysis terms) both in the nonprofit and political networks in 2011 (during Hu's presidency, transitivity $=0.23$ ). These cliques dissolved in 2013 (the year of presidential change, transitivity $=0.13$ ) and then began to form again in 2015 (during Xi's presidency, transitivity $=0.14)^{7}$

By analyzing the types of connections between individuals (e.g., between the CCP and State Council, the CCP and the PC, and the CCP and the PCC; Fig. 4), we can better understand how formal political institutions orchestrate policy in the nonprofit sector. As Fig. 4 presents, the links between different political organizations consistently make up more than $70 \%$ of all connections in all years observed. In contrast to many beliefs about authoritarian regimes, where the ruling party dominates the polity, the Chinese political system is quite pluralistic and collaborative.

The connections between and within the CCP and State Council are consistently the highest, indicating the close relationship between the two political groups and their important roles in influencing the nonprofit sector. The CCP-State Council coalition separates two institutional spaces: a legislative space with the $\mathrm{PC}$ and a political participation space with the PCC. The two institutional spaces would not be able to reach each other without routing through the CCP-State Council coalition in all years observed. Such a coalition also resembles the politics-administration tension studied in democracies $[37,38,55]$.

A shift from the PC to the PCC as the main entity tied to the CCP-State Council coalition occurred after the leadership change from $\mathrm{Hu}$ to $\mathrm{Xi}$. In 2011 and 2012 (during Hu's presidency), it was the PC that connected to the CCP-State Council coalition; between 2013 and 2015 (during Xi's presidency), the PCC assumed the PC's role. The shift from the PC to the PCC indicates both an institutional improvement and a retreat. In theory, the PCC is an important institution for non-CCP elites' political participation. Policy bargaining and participation within the PCC will not threaten the CCP's hegemony because the PCC has no legislative authority [23, 78]. The close relationship between the

\footnotetext{
${ }^{7}$ Transitivity for the other years: 2012, 0.21 and 2014, 0.10.
} 


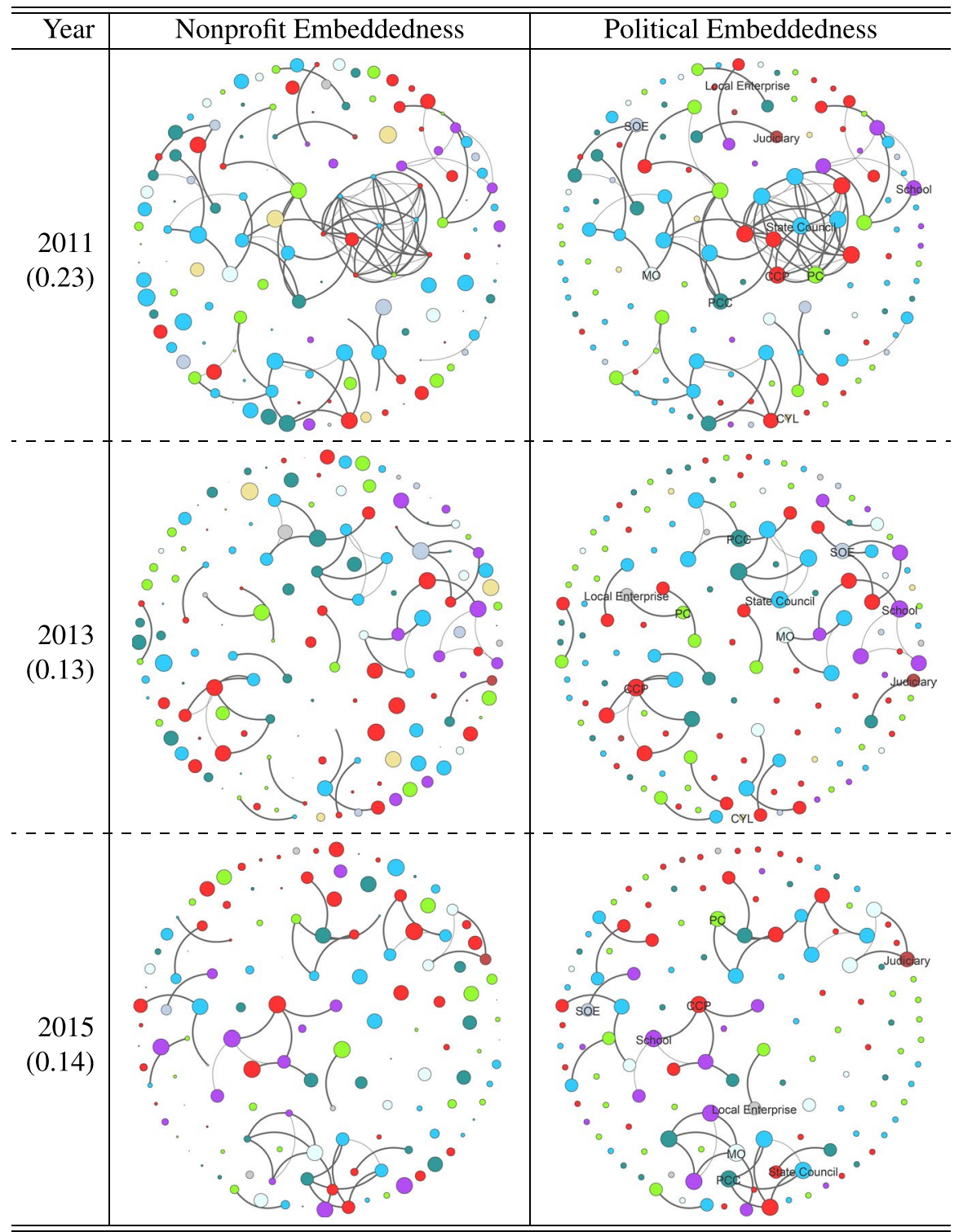

Fig. 3 Nonprofit and political embeddedness of political elites. Notes: The nonprofit and political networks are pluralistic, and dense cliques are observed in 2011 and then dissolved and reformed afterwards. Nodes represent political elites. Node size represents standardized node degree using $\log _{100}\left(e^{\text {PctlRank }}\right)$, where $e$ is Euler's number and PctlRank is the percentile rank of the raw node degree. Node colors represent political affiliations and are consistent across different years. Bold edges connect nodes with different political affiliations. The two networks for the same year use the same KamadaKawai layout (i.e., an elite's position in different networks does not change for a given year; [30]). Numbers in parentheses represent network transitivity. $\mathrm{CCP}=$ Chinese Communist Party; CYL $=$ Communist Youth League; $\mathrm{MO}=$ Mass Organization; $\mathrm{PC}=$ People's Congress; PCC = Political Consultative Conference; $\mathrm{CSOE}=$ Central state-owned enterprise; $\mathrm{LSOE}=$ Local state-owned enterprise 

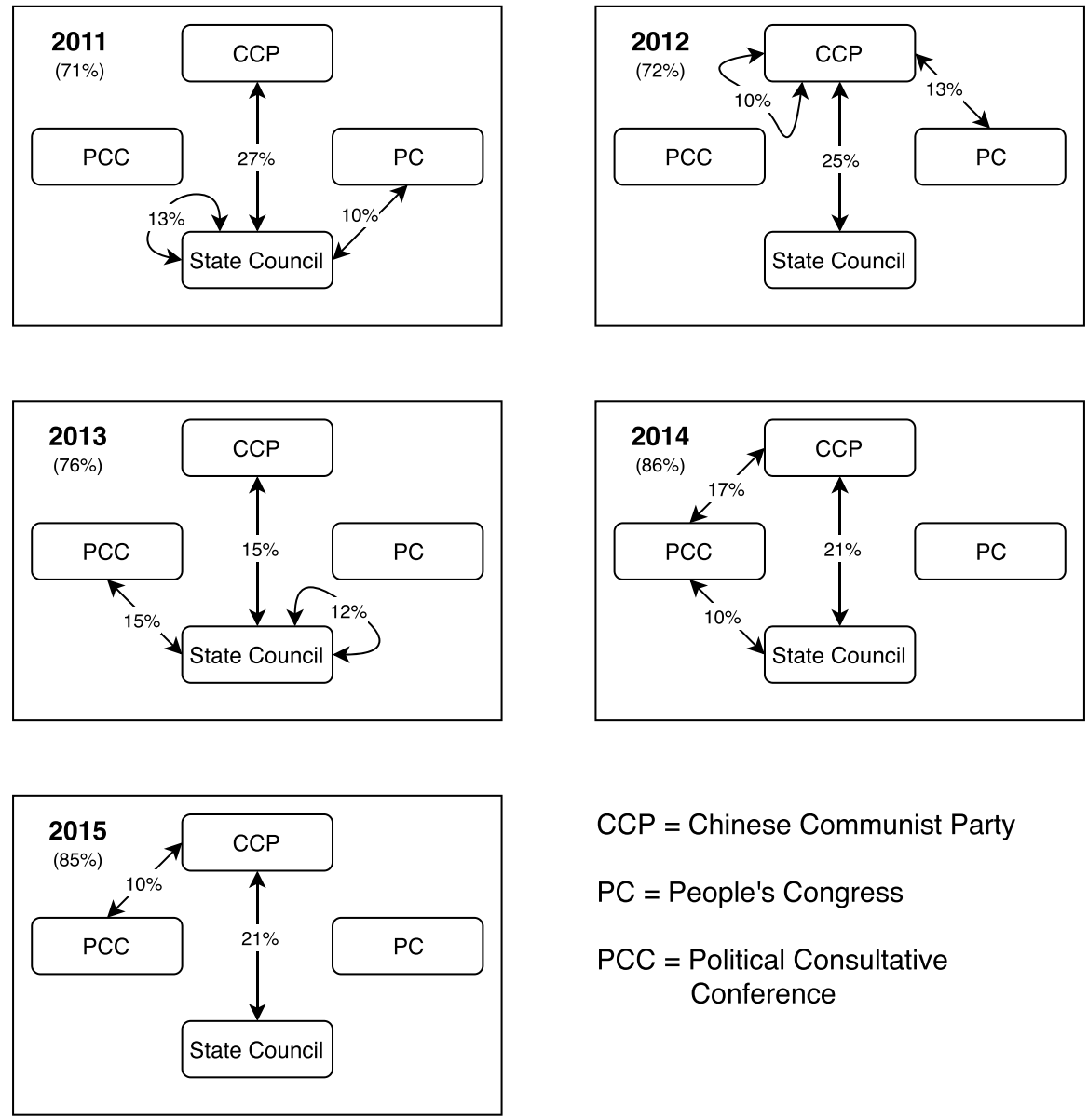

$$
\begin{aligned}
& \text { CCP }=\text { Chinese Communist Party } \\
& \text { PC }=\text { People's Congress } \\
& \text { PCC }=\text { Political Consultative } \\
& \text { Conference }
\end{aligned}
$$

Fig. 4 Links between political institutions: Separating political participation and legislation. Notes: The CCP-State Council coalition separates two institutional spaces. The space on the left has PCC for political participation, and that on the right has PC for legislation. Only showing links greater than $10 \%$ of the total connections. Percentages in parentheses represent the proportion of links that connect different political institutions. Detailed statistics and raw counts are in Table S6

PCC and the ruling party is propitious for building an inclusive regime, but the detachment of the PC from the CCP signals a retreat because the PCC cannot reach the final legislative body, even though it can reach the ruling party.

There was also a shift from the State Council to the CCP as the primary institutional broker during the two presidencies. The PC and PCC were both connected to the State Council initially, but they all ultimately switched their connections to the CCP. In all the years observed, the PCC had no or a low $(<2.6 \%)$ number of direct or indirect connections with the PC. Thus, the CCP has built itself as a necessary broker in the institutional network.

In general, the structures of the individual and institutional networks show the pluralism under authoritarianism. The connections between political elites 
are widespread and diverse, and they systematically differ across presidencies. The institutional political networks embedded in the nonprofit sector separate legislation and political participation by blocking non-CCP institutions from reaching legislative authority - a key strategy for balancing civic participation and the ruling party's hegemony.

\section{Predicting Embeddedness in Nonprofit Foundations}

\section{Main Regression Results: A Strategy of Differentiated Embeddedness}

Table 5 presents more inferential statistics by regressing political affiliations and controls on nonprofit and political network degrees in both presidencies. ${ }^{8}$ The table reveals some presidential differences: compared to Hu's presidency, CSOE's nonprofit embeddedness and CYL's political embeddedness dropped substantially in Xi's presidency, whereas the political embeddedness of MO, PCC, and School significantly increased. The results of CYL are worth highlighting as well: the CYL cadres had larger degrees of nonprofit embeddedness, but were marginalized in the political arena. Such a pattern survived the presidential change.

The estimations of the current presidency can be grouped into four categories as Table S5 in the appendix summarizes. 1) Strong nonprofit embeddedness includes CYL. 2) Weak nonprofit embeddedness includes Judiciary, LSOE, State Council, and CSOE. 3) Strong political embeddedness includes MO, State Council, and School. And 4) weak political embeddedness includes CYL and CSOE.

\section{Checking Robustness: Considering Presidential Preferences and Diversity of Embeddedness}

As Table 6 presents, the addition of embeddedness diversity and previous CYL experience substantially improves the adjusted $R^{2}$ of the models that predict embeddedness in the political network (from just over 0.1 to almost 0.6). Statistically, the test is effective because the stability of coefficients and the increase of $R^{2}$ are beneficial to evaluate robustness [50].

Table 6 confirms the differentiated embeddedness presented in Tables 5 and S5. It also supports the anecdotal observations of China's fractured political system $[59,60]$. Hu was the head of the CYL, and his presidency has been considered to have ushered in the rise of the CYL Clique [32]. As Table 6 shows, previous CYL work experience could help a cadre gain a significant political advantage under Hu's administration. But during Xi's presidency, such a privilege disappears, and current CYL leaders were also marginalized in the polity.

\footnotetext{
${ }^{8}$ In general, more observations can generate smaller standard errors in regression analysis, resulting in more significant estimates. Accepting these estimates as significant can increase the risk of false positive conclusions (i.e., false claims accepted as true). Given the relatively small number of observations we have here, we are susceptible to the risk of false negative conclusions (i.e., true claims not supported by the analysis) but not false positive conclusions. This actually adds more confidence to the findings because the significant estimates are less likely to be false.
} 
Table 5 Embeddedness of political elites in networks

\begin{tabular}{|c|c|c|c|c|c|c|}
\hline & \multicolumn{3}{|c|}{ Nonprofit Embeddedness } & \multicolumn{3}{|c|}{ Political Embeddedness } \\
\hline & $H u$ & $X i$ & $\chi^{2}$ & $H u$ & $X i$ & $\chi^{2}$ \\
\hline \multicolumn{7}{|c|}{ Political Affiliation } \\
\hline $\mathrm{CCP}$ & $\begin{array}{l}-.04 \\
(.12)\end{array}$ & $\begin{array}{l}-.03 \\
(.09)\end{array}$ & .01 & $\begin{array}{l}.08 \\
(.36)\end{array}$ & $\begin{array}{l}.07 \\
(.08)\end{array}$ & .00 \\
\hline CYL & $\begin{array}{l}1.27 * * \\
(.62)\end{array}$ & $\begin{array}{l}1.15^{* * * *} \\
(.34)\end{array}$ & .03 & $\begin{array}{l}-1.43 * * * \\
(.41)\end{array}$ & $\begin{array}{l}-.43 * * * \\
(.15)\end{array}$ & $5.80 * *$ \\
\hline Judicial & $\begin{array}{l}-.10 \\
(.08)\end{array}$ & $\begin{array}{l}-.18^{* * * *} \\
(.07)\end{array}$ & .86 & $\begin{array}{l}-.14 \\
(.29)\end{array}$ & $\begin{array}{l}.39 \\
(.30)\end{array}$ & 2.3 \\
\hline LSOE & $\begin{array}{l}-.07 \\
(.10)\end{array}$ & $\begin{array}{l}-.20^{* * *} \\
(.07)\end{array}$ & .15 & $\begin{array}{l}-.53^{*} \\
(.32)\end{array}$ & $\begin{array}{l}-.11 \\
(.14)\end{array}$ & 1.8 \\
\hline MO & $\begin{array}{l}.09 \\
(.20)\end{array}$ & $\begin{array}{l}-.11 \\
(.10)\end{array}$ & 1.00 & $\begin{array}{l}-.64 * \\
(.36)\end{array}$ & $\begin{array}{l}.29 * * \\
(.14)\end{array}$ & $6.30 * *$ \\
\hline PCC & $\begin{array}{l}.03 \\
(.09)\end{array}$ & $\begin{array}{l}-.08 \\
(.07)\end{array}$ & 1.10 & $\begin{array}{l}-.34 \\
(.27)\end{array}$ & $\begin{array}{l}.12 \\
(.09)\end{array}$ & $3.4^{*}$ \\
\hline State Council & $\begin{array}{l}.09 \\
(.16)\end{array}$ & $\begin{array}{l}-.14^{*} \\
(.08)\end{array}$ & 1.70 & $\begin{array}{l}-.06 \\
(.38)\end{array}$ & $\begin{array}{l}.18^{* *} \\
(.09)\end{array}$ & .45 \\
\hline CSOE & $\begin{array}{l}.16 \\
(.21)\end{array}$ & $\begin{array}{l}-.24^{* *} \\
(.11)\end{array}$ & $3.8^{*}$ & $\begin{array}{l}-.60^{* *} \\
(.28)\end{array}$ & $\begin{array}{l}-.41^{* * * *} \\
(.13)\end{array}$ & .52 \\
\hline School & $\begin{array}{l}.05 \\
(.14)\end{array}$ & $\begin{array}{l}.15 \\
(.15)\end{array}$ & .25 & $\begin{array}{l}-.23 \\
(.33)\end{array}$ & $\begin{array}{l}.33 * * \\
(.14)\end{array}$ & $2.8^{*}$ \\
\hline \multicolumn{7}{|l|}{ Controls } \\
\hline Male & $\begin{array}{l}.05 \\
(.13)\end{array}$ & $\begin{array}{l}-.12 \\
(.13)\end{array}$ & .97 & $\begin{array}{l}-.17 \\
(.34)\end{array}$ & $\begin{array}{l}-.16 \\
(.13)\end{array}$ & 0 \\
\hline Education & $\begin{array}{l}.02 \\
(.03)\end{array}$ & $\begin{array}{l}-.04 \\
(.02)\end{array}$ & $3.00 *$ & $\begin{array}{l}-.04 \\
(.10)\end{array}$ & $\begin{array}{l}.05^{* *} \\
(.02)\end{array}$ & .76 \\
\hline Cadre rank & $\begin{array}{l}.00 \\
(.02)\end{array}$ & $\begin{array}{l}-.02 \\
(.01)\end{array}$ & .58 & $\begin{array}{l}-.02 \\
(.04)\end{array}$ & $\begin{array}{l}-.01 \\
(.02)\end{array}$ & .05 \\
\hline Age & $\begin{array}{l}-.05 \\
(.04)\end{array}$ & $\begin{array}{l}-.09 * * * \\
(.03)\end{array}$ & .81 & $\begin{array}{l}-.12 \\
(.09)\end{array}$ & $\begin{array}{l}-.03 \\
(.04)\end{array}$ & .75 \\
\hline Board size & $\begin{array}{l}.68^{* * * *} \\
(.02)\end{array}$ & $\begin{array}{l}.78^{* * *} \\
(.02)\end{array}$ & $8.70^{* * *}$ & $\begin{array}{l}.44 * * * \\
(.06)\end{array}$ & $\begin{array}{l}.19 * * * \\
(.03)\end{array}$ & $15^{* * *}$ \\
\hline \#Observations & 277 & 431 & & 277 & 431 & \\
\hline Adjusted $R^{2}$ & .51 & .70 & & .11 & .14 & \\
\hline
\end{tabular}

Dependent variable $=$ Network degree. $\mathrm{PC}$ is the base group for political affiliation. Network degree, age, and board size are transformed to $z$-scores. Bootstrap standard errors are in parentheses [63]. $\chi^{2}$ column shows the results of Wald test. $C C P=$ Chinese Communist Party; $C Y L=$ Communist Youth League; $M O=$ Mass Organization; $P C=$ People's Congress; $P C C=$ Political Consultative Conference; CSOE = Central state-owned enterprise; $L S O E=$ Local state-owned enterprise. ${ }^{*} p<.1,{ }^{* *} p<.05,{ }^{* * *} p<$ .01 , two-tailed tests 
Another concern is the All-China Women's Federation (ACWF), which has occupied a unique role between the party-state and civil society since its creation [71]. ${ }^{9}$ Melting it with other organizations in the MO category may introduce a heterogeneity problem to the measure. I tested this concern by removing ACWF cadres from the regression analysis, and Table S7 in the Appendix shows no substantial difference. According to my analysis, ACWF individuals are not heavily embedded in nonprofit foundations. This finding is congruent with their operating strategy- "the politics of concealment": they camouflage their agenda using the party's language and efface themselves by attributing accomplishments to the party's leaders [71, 17-18]. Although this robustness test does not alter the findings, it cautions us that the negotiation between political and civil actors can happen through other channels and that the findings should thus not be overgeneralized.

\section{Qualitative Member Checking}

Following the member checking procedures described earlier, I conducted a series of interviews and focus groups. The fieldwork generally confirmed the findings, and the appendix has more details.

\section{Discussion}

By studying over two hundred high-profile political elites embedded in Chinese nonprofit foundations from 2011 to 2015 , I conceptualized a framework of differentiated embeddedness to understand the relationship between the state and the nonprofit sector in China at the meso and micro levels. Table S5 summarizes the framework and primary results. According to the elites' embeddedness in the civil and political domains, they can be grouped into four categories. 1) Those who have strong horizontal connections in nonprofits are excellent state agents when it comes to reaching civic resources (i.e., the CYL). 2) Those who have strong vertical connections in the polity can serve as access points to the party-state (i.e., Mass Organization, intellectuals, and government bureaucracy). 3) Those who are less connected in nonprofits are weak state agents (i.e., the legal system, state-owned business, and the government bureaucracy). And 4) those who are less connected in the polity are ineffective access points to political resources (i.e., the CYL and state-owned business). The four groups of political elites constitute a strategy of differentiated embeddedness, which reminds students studying the relationship between the state and the nonprofit sector to shift their theoretical lens from a conventional dyadic paradigm to a network paradigm.

There are still a few lingering questions, first of which is the role of CCP in the differentiated framework. As the ruling party, it is not a dominant actor in all networks. Second, the special role of CYL should be detailed. Third, directions for future studies are worthy of discussion. The remaining sections clarify these questions.

\footnotetext{
${ }^{9}$ I thank an anonymous reviewer for pointing this out.
} 
Table 6 Robustness check: Embeddedness of political elites in networks

\begin{tabular}{|c|c|c|c|c|c|c|}
\hline & \multicolumn{3}{|c|}{ Nonprofit Embeddedness } & \multicolumn{3}{|c|}{ Political Embeddedness } \\
\hline & $H u$ & $X i$ & $\chi^{2}$ & $H u$ & $X i$ & $\chi^{2}$ \\
\hline \multicolumn{7}{|l|}{ Political Affiliation } \\
\hline $\mathrm{CCP}$ & $\begin{array}{l}-.03 \\
(.12)\end{array}$ & $\begin{array}{l}-.00 \\
(.09)\end{array}$ & .04 & $\begin{array}{l}.25 \\
(.24)\end{array}$ & $\begin{array}{l}.04 \\
(.06)\end{array}$ & .78 \\
\hline CYL & $\begin{array}{l}1.13^{*} \\
(.65)\end{array}$ & $\begin{array}{l}1.18^{* * * *} \\
(.37)\end{array}$ & .01 & $\begin{array}{l}-.29 \\
(.26)\end{array}$ & $\begin{array}{l}-.21 * * \\
(.11)\end{array}$ & .09 \\
\hline CYL exp. & $\begin{array}{l}.10 \\
(.17)\end{array}$ & $\begin{array}{l}.16 \\
(.11)\end{array}$ & .08 & $\begin{array}{l}.45^{* *} \\
(.20)\end{array}$ & $\begin{array}{l}.09 \\
(.06)\end{array}$ & $3.4^{*}$ \\
\hline Judicial & $\begin{array}{l}.03 \\
(.14)\end{array}$ & $\begin{array}{l}-.12 * \\
(.07)\end{array}$ & 1.20 & $\begin{array}{l}-.62 \\
(.49)\end{array}$ & $\begin{array}{l}.10 \\
(.15)\end{array}$ & 2.5 \\
\hline LSOE & $\begin{array}{l}-.12 \\
(.11)\end{array}$ & $\begin{array}{l}-.16^{* * *} \\
(.08)\end{array}$ & .11 & $\begin{array}{l}.17 \\
(.26)\end{array}$ & $\begin{array}{l}.09 \\
(.12)\end{array}$ & .09 \\
\hline MO & $\begin{array}{l}-.01 \\
(.20)\end{array}$ & $\begin{array}{l}-.10 \\
(.10)\end{array}$ & .16 & $\begin{array}{l}.10 \\
(.30)\end{array}$ & $\begin{array}{l}.24 * * \\
(.11)\end{array}$ & .24 \\
\hline PCC & $\begin{array}{l}.04 \\
(.10)\end{array}$ & $\begin{array}{l}-.06 \\
(.07)\end{array}$ & .81 & $\begin{array}{l}-.24 \\
(.21)\end{array}$ & $\begin{array}{l}.01 \\
(.07)\end{array}$ & 1.4 \\
\hline State Council & $\begin{array}{l}.13 \\
(.17)\end{array}$ & $\begin{array}{l}-.10 \\
(.08)\end{array}$ & 1.6 & $\begin{array}{l}-.10 \\
(.25)\end{array}$ & $\begin{array}{l}.02 \\
(.06)\end{array}$ & .24 \\
\hline CSOE & $\begin{array}{l}.09 \\
(.21)\end{array}$ & $\begin{array}{l}-.21^{*} \\
(.12)\end{array}$ & 2.1 & $\begin{array}{l}.10 \\
(.23)\end{array}$ & $\begin{array}{l}-.22 * * \\
(.11)\end{array}$ & 1.9 \\
\hline School & $\begin{array}{l}.10 \\
(.15)\end{array}$ & $\begin{array}{l}.19 \\
(.15)\end{array}$ & .21 & $\begin{array}{l}-.27 \\
(.25)\end{array}$ & $\begin{array}{l}.15^{*} \\
(.09)\end{array}$ & $3.0^{*}$ \\
\hline \multicolumn{7}{|l|}{ Controls } \\
\hline Male & $\begin{array}{l}.06 \\
(.13)\end{array}$ & $\begin{array}{l}-.13 \\
(.13)\end{array}$ & 1.3 & $\begin{array}{l}-.27 \\
(.21)\end{array}$ & $\begin{array}{l}-.21 * * \\
(.09)\end{array}$ & .07 \\
\hline Education & $\begin{array}{l}.02 \\
(.03)\end{array}$ & $\begin{array}{l}-.04 \\
(.02)\end{array}$ & $3.3^{*}$ & $\begin{array}{l}-.04 \\
(.06)\end{array}$ & $\begin{array}{l}.02 \\
(.02)\end{array}$ & .83 \\
\hline Cadre rank & $\begin{array}{l}.01 \\
(.02)\end{array}$ & $\begin{array}{l}-.01 \\
(.01)\end{array}$ & .72 & $\begin{array}{l}-.04 \\
(.03)\end{array}$ & $\begin{array}{l}-.02 \\
(.01)\end{array}$ & .84 \\
\hline Age & $\begin{array}{l}-.05 \\
(.05)\end{array}$ & $\begin{array}{l}-.08^{* * *} \\
(.03)\end{array}$ & .29 & $\begin{array}{l}-.01 \\
(.07)\end{array}$ & $\begin{array}{l}-.03 \\
(.03)\end{array}$ & .08 \\
\hline Board size & $\begin{array}{l}.74 * * * \\
(.03)\end{array}$ & $\begin{array}{l}.78 * * * \\
(.02)\end{array}$ & 2.3 & $\begin{array}{l}.10^{* * *} \\
(.04)\end{array}$ & $\begin{array}{l}.10^{* * *} \\
(.02)\end{array}$ & .00 \\
\hline Embed. diversity & $\begin{array}{l}.15 * * * \\
(.05)\end{array}$ & $\begin{array}{l}.03 \\
(.03)\end{array}$ & $5.1 * *$ & $\begin{array}{l}-.99 * * * \\
(.09)\end{array}$ & $\begin{array}{l}-.44 * * * \\
(.03)\end{array}$ & $33 * * *$ \\
\hline \#Observations & 277 & 431 & & 277 & 431 & \\
\hline Adjusted $R^{2}$ & .52 & .71 & & .57 & .57 & \\
\hline
\end{tabular}

Dependent variable $=$ Network degree. $\mathrm{PC}$ is the base group for political affiliation. Network degree, age, board size, and embeddedness diversity are transformed to $z$-scores. Bootstrap standard errors are in parentheses [63]. $\chi^{2}$ column shows the results of Wald test. CCP $=$ Chinese Communist Party; CYL $=$ Communist Youth League; CYL Exp. = Cadres with previous CYL work experience; MO = Mass Organization; $\mathrm{PC}=$ People's Congress; $\mathrm{PCC}=$ Political Consultative Conference; $\mathrm{CSOE}=\mathrm{Central}$ stateowned enterprise; LSOE = Local state-owned enterprise. ${ }^{*} p<.1,{ }^{* *} p<.05,{ }^{* * *} p<.01$, two-tailed tests 


\section{CCP as the Vanguard: Strategy for Supervising Foundations}

Veering away from conventional thoughts about authoritarianism, the Chinese political network leaves room for pluralism. As Fig. 3 shows, CCP leaders are not dominant actors in all political networks. Moreover, political leaders with different affiliations are widely interconnected, which provides a structural basis for the negotiations between different political groups. Meanwhile, CCP leaders are not the most connected political group in the foundations' board interlocking network either. The degree of CYL leaders' connections is twice as great as that of the CCP leaders', indicating that many more social elites are connected with CYL cadres than CCP cadres. We can speculate that the CCP's influence in the nonprofit sector may be mostly "behind the scenes," so it is not as direct as we conventionally assume.

However, if we conclude that the nonprofits and the polity are sufficiently pluralistic to threaten the CCP's control, we are missing the unique features of the multilayered network system-in the party's official narrative, the CCP should serve as the vanguard of the polity, and its leadership, even without having direct control over all works, is the most essential feature of "socialism with Chinese characteristics."

One strategy is to build the CCP as an essential broker to reach the PC, the legislative authority in the political network. The institutional space in Fig. 4 is separated into two: the left PCC space for political participation and the right PC space for legislation. By routing all connections through $\mathrm{CCP}$, the party creates room for political participation while securing access to legislation. Yan $[78,75]$ suggested that the CCP needs to "have an overwhelming majority in the PC to control legislative power, but intentionally keeps itself as minority in the [PCC]." I advance this control strategy further-it is not only the number of individuals that matters but also how they are organized.

Another strategy is to embed party branches in nonprofits directly. As the Regulations on the Operation of the Party Branches states, any "unit" with three or more CCP members shall establish a party branch. The party branches are independent political organizations and only report to the CCP system. Although not examined in this paper, it would be intriguing to study how these party branches function.

\section{Differentiated Embeddedness and the Chinese Youth League}

The CYL cadres were far younger than the non-CYL cadres at the same rank, indicating that they gained a substantial age advantage in promotion that may have helped them institutionalize the formation of the CYL Clique [32, 162]. As a result, although the CYL is meant to prepare youths to be the CCP's "assistants and reserve army," it is also a potential rival to the CCP in the polity. Many anecdotal papers have reported the CYL to be one of the major factions within the Chinese political system [11, 35, 36]. This paper supports these claims with empirical resultsalthough political elites could not enter the political network while they were active CYL cadres, those with previous CYL work experience were significantly favored in Hu's administration (Table 6). 
The CYL system plays important roles in developing volunteerism and grassroots nonprofits $[69,77]$, but such roles are limited to the grassroots level and are marginalized, even isolated, in the political network. This study reveals that the CYL cadres are the most connected political leaders in nonprofit networks but that their connections are unquestionably restricted-CYL leaders have no connections in the political network. Their cadre ranks tend to be low as well: all CYL leaders in this study were Bureau/Department leaders at the local level (Table 3), indicating that they were unable to reach the center of the polity directly.

The CYL actors are marginalized in political networks because of numerous institutional and promotional arrangements. For example, CYL leaders have to "reenter" the regular party or governmental departments through other political channels [14, 54]. As of 2019, all CYL leaders in my dataset had been reassigned to $\mathrm{CCP}$ or bureaucratic positions. Moreover, Xi made a series of reforms to "keep CYL leaders grassroots" [7] and required CYL leaders to be "youths' friends but not young cadres" [52]. The youth organizations are also decentralized, preventing CYL leaders from forming cohesive political groups [14, 439]. In all scenarios, we can expect that 1) the CYL leaders' future political careers and decisions can be influenced by their social roles and experience obtained from nonprofits and that 2) these leaders are strategically placed by the CCP so that their autonomy is limited in the party-state.

\section{Policy Implication and Future Directions}

The connections between the party-state and nonprofits have already been institutionalized following a strategy of differentiated embeddedness. However, this embeddedness is inefficient. Effective communication between the state and the nonprofit sector requires elites to have strong connections in both the civil and political domains, but the Chinese political elites who are well embedded in the nonprofit sector are disconnected from the polity, and those connected in the polity are weakly tied to nonprofits. The CYL elites are the most promising group that can bridge the civil and political spaces because they are widely connected in nonprofits. However, the party-state cannot effectively absorb social elites and receive feedback from the nonprofit sector if it keeps marginalizing CYL leaders in the polity.

Mass Organizations, intellectuals, and the government bureaucracy are all limited in serving as brokers. For example, Mass Organizations have been criticized as being institutionally bureaucratic and "out of touch with the people" [74]. Intellectuals, especially political scientists, can be widely co-opted by the state [49]. Moreover, government officials have been strictly regulated with regard to their involvement in the nonprofit sector [75].

Governing the relationship between the state and the nonprofit sector in authoritarian China is not an easy task, and the framework of differentiated embeddedness may only serve as a stimulus for future projects. As discussed previously, this study has numerous limitations regarding data sources and concept operationalization, and the findings and conclusions should be interpreted within the context of nonprofit foundations. Scholars can advance this topic from two general perspectives to 
improve the research design and generalizability. First, future studies should include data that can better describe the elites' connections within political domains (e.g., their coappearances in political events; [27]). Second, the longitudinal observation of the embedding strategy is worth tracking. The Charity Law of the People's Republic of China was officially released in early 2016 and represents a landmark in the development of the Chinese nonprofit sector. Furthermore, many sociopolitical situations have changed since 2015. Has the embedding strategy stayed consistent after 2015, and will it stay so throughout Xi's presidency? How do the elites' roles evolve over time? This study provides a snapshot of the pre-2015 period, which future studies can compare their findings to.

Supplementary Information The online version contains supplementary material available at https://oi. org/10.1007/s11366-022-09796-1.

Acknowledgements This paper was presented at the 2019 Annual MPSA Conference in Chicago, 2019 West Coast Nonprofit Data Conference in Phoenix, 2019 Guanxi for Guanxi Studies in Beijing, and LBJ Washtington DC Center. I thank Andy Zhao, Franziska Barbara Keller, Jeremi Suri, Jiar-der Luo, Joseph Galaskiewicz, Joshua Eisenman, Karl Johnson, Meiying Xu, Ronald Burt, Sonja Opper, Steven Klein, and conference attendees for their constructive comments and help. I thank Julie Yu-wen Chen and Sujian Guo for handling this manuscript and the anonymous reviewers for their valuable comments. I thank Angela Vimuttinan for proofreading and editing.

Funding The project is partly funded by the 2019 Faculty Research Program of the IC2 Institute and the Academic Development Funds from the RGK Center.

\section{Declarations}

Ethics approval The author declares that this study complies with required ethical standards.

Conflict of Interests The author declares no known conflict of interest.

Open Access This article is licensed under a Creative Commons Attribution 4.0 International License, which permits use, sharing, adaptation, distribution and reproduction in any medium or format, as long as you give appropriate credit to the original author(s) and the source, provide a link to the Creative Commons licence, and indicate if changes were made. The images or other third party material in this article are included in the article's Creative Commons licence, unless indicated otherwise in a credit line to the material. If material is not included in the article's Creative Commons licence and your intended use is not permitted by statutory regulation or exceeds the permitted use, you will need to obtain permission directly from the copyright holder. To view a copy of this licence, visit http://creativecommons.org/licen ses/by/4.0/.

\section{References}

1. Ang Yuen Yuen. 2012. Counting cadres: A comparative view of the size of China's Public Employment [in en]. The China Quarterly 211: 676-696. https://doi.org/10.1017/S0305741012000884. Accessed 5 Mar 2019.

2. Barnes Roy C. 2017. Structural redundancy and multiplicity within networks of US Corporate Directors [in en]. Critical Sociology 43(1): 37-57. https://doi.org/10.1177/0896920515580177. Accessed 8 May 2017.

3. Bennett Andrew. 2010. Process Tracing and Causal Inference. Rethinking Social Inquiry: Diverse Tools, Shared Standards, 00457. Rowman \& Littlefield Publishers. 
4. Bo Zhiyue. 2012. State power and governance structures [in English]. Handbook of China's Governance and Domestic Politics, 1st ed., ed. Chris Ogden. Milton Park, Abingdon, Oxon ; New York, Routledge. 00008.

5. Brødsgaard Kjeld Erik. 2012. Politics and Business Group Formation in China: The Party in Control? [In en]. 00134. The China Quarterly 211: 624-648. https://doi.org/10.1017/S03057410120008 11. Accessed 11 March 2019.

6. Brødsgaard Kjeld Erik. 2018. China's Communist Party: From Mass to Elite Party [in en]. 00000. China Report 54(4): 385-402. https://doi.org/10.1177/0009445518806076. Accessed 5 March 2019.

7. Buckley Chris. 2018. China Reins In Communist Youth League, and Its Alumni's Prospects [in en-US]. 00003, The New York Times. https://www.nytimes.com/2016/08/04/world/asia/chinacommunist-youth-league.html. Accessed 28 Jan 2019.

8. Burt Ronald S. 1992. Structural holes: the social structure of competition. Cambridge, Mass: Harvard University Press. 00012.

9. Chamberlain Heath B. 1993. On the search for civil society in China. Modern China 19(2): 199215. http://www.jstor.org/stable/189380. Accessed 18 Mar 2016.

10. Chan Hon S., and Edward Li Suizhou. 2007. Civil Service Law in the People's Republic of China: A Return to Cadre Personnel Management [in en]. 00116. Public Administration Review 67(3): 383-398. https://doi.org/10.1111/j.1540-6210.2007.00722.x. Accessed 16 Jan 2019.

11. Chen Yunzhe. 2015. The Relationship between the CCYL and the CCP, 1920-2012: From Organizational Rival to Leadership Incubator [in en]. 00000. Doctor of Philosophy, University of New South Wales.

12. John W. Creswell, and Vicki L. Plano Clark. 2017. Core mixed methods designs [in en]. Designing and Conducting Mixed Methods Research. 00018 Google-Books-ID: BXEzDwAAQBAJ. SAGE Publications.

13. Davis Gerald F. 1996. The significance of board interlocks for corporate governance. 00157. Corporate Governance: An International Review 4 (3): 154-159. http://onlinelibrary.wiley.com/ doi/10.1111/j.1467-8683.1996.tb00144.x/full. Accessed 15 Aug 2016.

14. Doyon Jerome. 2017. Rejuvenating Communism: The Communist Youth League as a Political Promotion Channel in Post-Mao China [in English]. 00000. Ph.D., Columbia University. https://search. proquest.com/docview/1898803802/abstract/56A241C6419841ACPQ/1. Accessed 15 Dec 2018.

15. Esparza Nicole, and So Hee Jeon. 2013. Interlocking Boards of Trustees and Grant Acquisition Among Homeless Service Organizations. 00012. Public Performance \& Management Review 36 (4): 637-664. https://doi.org/10.2753/PMR1530-9576360407. Accessed 10 June 2016.

16. Farid May, and Chengcheng Song. 2020. Public Trust as a Driver of State-Grassroots NGO Collaboration in China [in en]. 5 citations (Crossref) [2022-02-27]. Journal of Chinese Political Science 25(4): 591-613. https://doi.org/10.1007/s11366-020-09691-7. Accessed 28 Feb 2022.

17. Faulk Lewis, Willems Jurgen, Jasmine McGinnis Johnson, and Amanda J. Stewart. 2016. Network Connections and Competitively Awarded Funding: The impacts of board network structures and status interlocks on nonprofit organizations' foundation grant acquisition 00024. eprint: https://doi.org/10.1080/14719037.2015.1112421 tex.ids: FaulkNetworkConnectionsCompetitively2015 publisher: Routledge, Public Management Review 18 (10): 1425-1455. Accessed June 8, 2020. https://doi.org/10.1080/14719037.2015.1112421.

18. Goldman Merle, and Edward Gu, (eds). 2004. Chinese Intellectuals Between State and Market [in English] 00085, 1st ed. London; New York, Routledge.

19. Granovetter Mark. 1973. The Strength of Weak Ties. 51393. American Journal of Sociology 78(6): 1360-1380. http://www.jstor.org/stable/2776392. Accessed 25 Oct 2014.

20. Guo Dingping. 2020. Xi's Leadership and Party-Centred Governance in China [in en]. 8 citations (Crossref) [2022-02-27]. Chinese Political Science Review 5(4): 439-456. https://doi.org/ 10.1007/s41111-020-00149-y. Accessed 28 Feb 2022.

21. Hasmath Reza, Timothy Hildebrandt, and Jennifer Y. J. Hsu. 2019. Conceptualizing governmentorganized non-governmental organizations. 00000. Journal of Civil Society 15(3): 267-284. Publisher: Routledge eprint: https://doi.org/10.1080/17448689.2019.1632549. Accessed 28 Oct 2020.

22. Hasmath Reza, and Jennifer Y. J. Hsu. 2020. A Community of Practice for Chinese NGOs [in en]. 8 citations (Crossref) [2022-02-27]. Journal of Chinese Political Science 25 (4): 575-589. https://doi. org/10.1007/s11366-020-09687-3. Accessed 28 Feb 2022.

23. He Baogang, and Stig Thøgersen. 2010. Giving the People a Voice? Experiments with consultative authoritarian institutions in China. 00136. Journal of Contemporary China 19(66): 675-692. https://doi.org/10.1080/10670564.2010.485404. Accessed 28 Dec 2018. 
24. Heurlin Christopher. 2010. Governing Civil Society: The Political Logic of NGOState Relations Under Dictatorship [in en]. 00118. VOLUNTAS: International Journal of Voluntary and Nonprofit Organizations 21(2): 220-239. https://doi.org/10.1007/s11266-009-9103-2. Accessed 30 Jan 2021.

25. Holland Paul W., and Samuel Leinhardt. 1970. A Method for Detecting Structure in Sociometric Data. 00529. American Journal of Sociology 76(3): 492-513. https://www.jstor.org/stable/2775735. Accessed 9 April 2019.

26. Holland Paul W., and Samuel Leinhardt. 1971. Transitivity in Structural Models of Small Groups [in en]. 00567. Comparative Group Studies 2 (2): 107-124. https://doi.org/10.1177/1046496471 00200201. Accessed 9 April 2019.

27. Huhe Narisong, Max Gallop, and Shahryar Minhas. 2021. Who are in charge, who do I work with, and who are my friends: A latent space approach to understanding elite coappearances in China [in en]. 00000. Social Networks 66: 26-37. https://doi.org/10.1016/j.socnet.2021.01.002. Accessed 13 Feb 2021.

28. Jane Duckett. 2012. Health and social policy [in English] 00008. Handbook of China's Governance and Domestic Politics, 1st ed., ed. Ogden Chris. Milton Park, Abingdon, Oxon; New York, Routledge.

29. Jiang Junyan. 2018. Making Bureaucracy Work: Patronage Networks, Performance Incentives, and Economic Development in China [in en]. 00005. American Journal of Political Science 62(4): 982999. https://doi.org/10.1111/ajps.12394. Accessed 18 Feb 2019.

30. Kamada Tomihisa, and Satoru Kawai. 1989. An algorithm for drawing general undirected graphs. 02926. Information Processing Letters 31 (1): 7-15. https://doi.org/10.1016/0020-0190(89)901026. Accessed 30 Jan 2019.

31. Kang Xiaoguang, and Heng Han. 2008. Graduated Controls: The State-Society Relationship in Contemporary China [in en]. 105 citations (Crossref) [2022-03-04], Publisher: SAGE Publications Inc. Modern China 34 (1): 36-55. https://doi.org/10.1177/0097700407308138. Accessed 7 Feb 2022.

32. Kou Chien-Wen, and Wen-Hsuan Tsai. 2014. "Sprinting with Small Steps" Towards Promotion: Solutions for the Age Dilemma in the CCP Cadre Appointment System. 00051. The China Journal 71: 53-171. https://doi.org/10.1086/674558. Accessed 15 Dec 2018.

33. Lai Weijun, Jiangang Zhu, Lin Tao, and Anthony J. Spires. 2015. Bounded by the State: Government Priorities and the Development of Private Philanthropic Foundations in China. 00011. The China Quarterly 224: 1083-1092. https://doi.org/10.1017/S030574101500123X. Accessed 14 April 2016.

34. Levy Katja, and Knut B. Pissler. 2020. Charity with Chinese Characteristics. 00005. Cheltenham, UK: Edward Elgar Publishing. https://www.elgaronline.com/view/9781788115063.xml.

35. Li Cheng. 2009. China's Team of Rivals. 00041, Foreign Policy, no. 171, 88-93. https://www.jstor. org/stable/20684856. Accessed 14 Dec 2018.

36. Li Cheng. 2012. The End of the CCP's Resilient Authoritarianism? A Tripartite Assessment of Shifting Power in China* [in en]. 00000. The China Quarterly 211: 595-623. https://doi.org/10. 1017/S0305741012000902. Accessed 14 Dec 2018.

37. Long Norton E. 1949. Power and Administration [in en]. 00472. Public Administration Review 9(4): 257. https://doi.org/10.2307/972337. Accessed 10 Sept 2018.

38. Long Norton E. 1952. Bureaucracy and Constitutionalism. 00338. The American Political Science Review 46(3): 808-818. https://doi.org/10.2307/1952286. Accessed 10 Sept 2018.

39. Lu Yao, and Ran Tao. 2017. Organizational Structure and Collective Action: Lineage Networks, Semiautonomous Civic Associations, and Collective Resistance in Rural China.” 00009. American Journal of Sociology 122(6): 1726-1774. https://doi.org/10.1086/691346. Accessed 4 June 2017.

40. Ma Ji. 2020. Funding nonprofits in a networked society: Toward a network framework of government support [in en]. Nonprofit Management and Leadership 31(2): 233-257. 00000 eprint: https:// doi.org/10.1002/nml.21426. Accessed 28 Jan 2021.

41. Ma Ji, and Simon DeDeo. 2018. State power and elite autonomy in a networked civil society: The board interlocking of Chinese non-profits. 00022. Social Networks 54: 291-302. https://doi.org/10. 1016/j.socnet.2017.10.001. Accessed 11 May 2018.

42. Ma Ji, Qun Wang, Chao Dong, and Huafang Li. 2017. The research infrastructure of Chinese foundations, a database for Chinese civil society studies [in en]. 00023. Scientific Data 4: sdata201794. https://doi.org/10.1038/sdata.2017.94. Accessed 29 July 2017.

43. Ma Qiusha. 2002. Defining Chinese Nongovernmental Organizations [in en]. 00000 c84. Voluntas: International Journal of Voluntary and Nonprofit Organizations 13(2): 113-130. https://doi.org/10. 1023/A:1016051604920. Accessed 7 May 2015.

44. Madsen, Richard. 1993. The Public Sphere, Civil Society and Moral Community: A Research Agenda for Contemporary China Studies. 00144. Modern China 19(2): 183-198. http://www.jstor. org/stable/189379. Accessed 8 April 2016. 
45. Mertha Andrew. 2009. "Fragmented Authoritarianism 2.0": Political Pluralization in the Chinese Policy Process [in en]. 00513. The China Quarterly 200: 995-1012. https://doi.org/10.1017/S0305 741009990592. Accessed 30 Dec 2018.

46. Migdal Joel S. 2001. State in Society: Studying How States and Societies Transform and Constitute One Another. Cambridge Studies in Comparative Politics. Cambridge: Cambridge University Press. https://doi.org/10.1017/CBO9780511613067.

47. Mizruchi Mark S. 1996. What do interlocks do? An analysis, critique, and assessment of research on interlocking directorates. 01572. Annual Review of Sociology: 271-298. http://www.jstor.org/stable/ 2083432. Accessed 15 Aug 2016.

48. Nie Lin, and Jie Wu. 2021. Strategic responses of NGOs to the new party-building campaign in China [in en]. Publisher: SAGE Publications Ltd, China Information, 0920203X21995705. https:// doi.org/10.1177/0920203X21995705. Accessed 9 Aug 2021.

49. Noakes Stephen. 2014. The Role of Political Science in China: Intellectuals and Authoritarian Resilience. 00017 Publisher: [The Academy of Political Science, Wiley]. Political Science Quarterly 129(2): 239-260. https://www.jstor.org/stable/43828651. Accessed 16 June 2020.

50. Oster Emily. 2019. Unobservable Selection and Coefficient Stability: Theory and Evidence. 00000. Journal of Business \& Economic Statistics 37 (2): 187-204. https://doi.org/10.1080/ 07350015.2016.1227711. Accessed 24 Nov 2019.

51. Padgett John F., and Paul D. McLean. 2006. Organizational Invention and Elite Transformation: The Birth of Partnership Systems in Renaissance Florence. 00239. American Journal of Sociology 111(5): 1463-1568. https://doi.org/10.1086/498470. Accessed 30 Sept 2015.

52. People's Daily. 2018. Be youths' friends, not young cadres. 00000. http://cpc.people.com.cn/ xuexi/n1/2018/0517/c385474-29995838.html. Accessed 3 July 2019.

53. PRC National People's Congress. 2005. Law of the People's Republic of China on Public Servants. 00000. http://www.npc.gov.cn/englishnpc/Law/2007-12/13/content1384101.htm. Accessed 16 Jan 2019.

54. Pringsheim Klaus H. 1962. The Functions of the Chinese Communist Youth Leagues* (19201949) [in en]. 00000. The China Quarterly 12: 75-91. https://doi.org/10.1017/S030574100 0020762. Accessed 24 Jan 2019.

55. Rosenbloom David. 2008. The Politics-Administration Dichotomy in U.S. Historical Context [in en]. 00102. Public Administration Review 68 (1): 57-60. https://doi.org/10.1111/j.1540-6210. 2007.00836.x. Accessed 10 Sept 2018.

56. Saich Tony. 2001. Governance and Politics of China [in English]. 00873. Houndmills, Basingstoke, Hampshire; New York: Palgrave Macmillan.

57. Tony Saich. 2015. Governance and Politics of China [in English], 4th ed. New York: Palgrave. 00891.

58. Salmenkari Taru. 2013. Theoretical Poverty in the Research on Chinese Civil Society [in en]. 00017. Modern Asian Studies 47(02): 682-711. https://doi.org/10.1017/S0026749X12000273. Accessed 18 March 2016.

59. Shih Victor, Christopher Adolph, and Mingxing Liu. 2012. Getting Ahead in the Communist Party: Explaining the Advancement of Central Committee Members in China. 00306 c104. American Political Science Review 106 (01): 166-187. https://doi.org/10.1017/S000305541 1000566. Accessed $10 \mathrm{Feb} 2015$.

60. Shih Victor C. 2016. Contentious elites in China: new evidence and approaches [in en]. 00007. Journal of East Asian Studies 16(1): 1-15. https://doi.org/10.1017/jea.2015.2. Accessed 13 Dec 2018.

61. Small Mario Luis. 2009. 'How many cases do I need?' On science and the logic of case selection in field-based research [in en]. 01165. Ethnography 10 (1): 5-38. https://doi.org/10.1177/14661 38108099586. Accessed Oct 82014.

62. Snape Holly, and Weinan Wang. 2020. Finding a place for the Party: debunking the "party-state" and rethinking the state-society relationship in China's one-party system. Journal of Chinese Governance 5(4): 477-502. 4 citations (Crossref) [2022-02-27] Publisher: Routledge eprint: https://doi.org/10.1080/23812346.2020.1796411. Accessed 28 Feb 2022.

63. Snijders Tom AB, and Stephen P. Borgatti. 1999. Non-parametric standard errors and tests for network statistics. 00157. Connections 22 (2): 161-170. http://citeseerx.ist.psu.edu/viewdoc/ download?doi=10.1.1.8.3077\&rep=rep1\&type $=$ pdf. Accessed 30 Nov 2015.

64. Song Esther. 2021. How Outsourcing Social Services to NGOs Bolsters Political Trust in China: Evidence from Shanghai [in en]. SSRN Scholarly Paper ID 3991317. Rochester, NY: Social Science Research Network. https://papers.ssrn.com/abstract=3991317. Accessed 28 Feb 2022. 
65. Spires Anthony J. 2011. Contingent Symbiosis and Civil Society in an Authoritarian State: Understanding the Survival of China's Grassroots NGOs. 00000. American Journal of Sociology 117(1): 1-45. https://doi.org/10.1086/660741. Accessed 26 Dec 2014.

66. Tao-Chiu Lam, and Hon S. Chan. 1996. Reforming China’s Cadre Management System: Two Views of a Civil Service. 00045. Asian Survey 36(8): 772-786. https://doi.org/10.2307/2645438. Accessed 27 Dec 2018.

67. Teets Jessica C. 2013. Let Many Civil Societies Bloom: The Rise of Consultative Authoritarianism in China [in en]. 00000. The China Quarterly 213: 19-38. https://doi.org/10.1017/S0305 741012001269. Accessed 27 Dec 2014.

68. Teets Jessica C. 2018. The power of policy networks in authoritarian regimes: Changing environmental policy in China [in en]. 00024. Governance 31 (1): 122-141. https://doi.org/10.1111/gove.12280. Accessed 16 Jan 2019.

69. Tsimonis Konstantinos. 2018. "Keep the Party Assured and the Youth [Not] Satisfied"s: The Communist Youth League and Chinese University Students [in en], 00000. Modern China 44(2): 170207. https://doi.org/10.1177/0097700417732561. Accessed 15 Dec 2018.

70. Wang Qun. 2018. A Typological Study of the Recent Development and Landscape of Foundations in China [in en]. 00004. Chinese Political Science Review 3(3): 297-321. https://doi.org/10.1007/ s41111-018-0094-2. Accessed 30 Jan 2020.

71. Wang Zheng. 2016. Finding Women in the State: A Socialist Feminist Revolution in the People's Republic of China, 1949-1964 [in en]. Accessed February 14, 2022.

72. Weng Shihong, and Yunxiang Zhang. 2020. Coproduction of community public service: evidence from china's community foundations. Journal of Chinese Governance 5(1): 90-109. 0 citations (Crossref) [2022-03-04] Publisher: Routledge eprint: https://doi.org/10.1080/23812346.2019.17100 48. Accessed 28 Feb 2022.

73. Wu Yan, Yuting Zhang, and Yutao Chen. 2021. The influence of board interlocking network centrality on foundation performance: evidence from China. Journal of Chinese Governance 6(1): 43-57. 2 citations (Crossref) [2022-03-04] Publisher: Routledge eprint: https://doi.org/10.1080/23812346. 2020.1841483. Accessed 28 Feb 2022.

74. Xinhua News Agency. 2015. Central Committee of the Chinese Communist Party's Opinion on Improving Mass Organizations' Operation. 00000. http://www.xinhuanet.com/politics/2015-07/09/ c1115875561.htm. Accessed 6 Oct 2020.

75. Xinhua News Agency. 2016. Reforming the Management System of Social Organizations. 00000. http://www.xinhuanet.com/politics/2016-08/21/c1119428034.htm. Accessed 6 Oct 2020.

76. Xinhua News Agency. 2018. Operating Regulations on Chinese Communist Party Branch. 00000. http://www.xinhuanet.com/politics/2018-11/25/c1123764501.htm. Accessed 11 March 2019.

77. Xu Ying. 2012. Chinese Communist Youth League, political capital and the legitimising of volunteering in China. 00013. International Journal of Adolescence and Youth 17(2-3): 95-112. https:// doi.org/10.1080/02673843.2012.656195. Accessed December 13, 2018.

78. Yan Xiaojun. 2011. Regime inclusion and the resilience of authoritarianism: the local people's political consultative conference in post-mao chinese politics. 00048. The China Journal 66: 53-75. https://doi.org/10.1086/tcj.66.41262807. Accessed 28 Dec 2018.

79. Zhang Zhibin, and Chao Guo. 2021. Nonprofit-Government Relations in Authoritarian China: A Review and Synthesis of the Chinese Literature [in en]. 4 citations (Crossref) [2022-01-21] tex.ids= ZhangNonprofitGovernmentRelationsAuthoritarian2020 publisher: SAGE Publications Inc. Administration \& Society 53(1): 64-96. https://doi.org/10.1177/0095399720934891. Accessed 14 Oct 2021.

80. Zheng Yongnian. 2010. The Party domination of the state [in English] 00000. The Chinese Communist Party as Organizational Emperor: Culture, reproduction, and transformation, 1st ed. London; New York, Routledge.

Publisher's Note Springer Nature remains neutral with regard to jurisdictional claims in published maps and institutional affiliations.

Ji Ma is an Assistant Professor in Nonprofit and Philanthropic Studies at the Lyndon B. Johnson School of Public Affairs and affiliated faculty member of the Center for East Asian Studies and the School of Information, UT Austin. He studies and teaches state-society relationship, knowledge production, and computational social science methods. 


\section{Online Supplementary Material: Data Preprocessing and Validation}

\section{Dataset Compilation and Structure}

The two datasets are linked by matching an individual's name, gender, and year of birth. Because the CPED codes an individual's work experience over time, I am able to identify individuals' political positions while they were serving as foundation board members.

Table S1: DESCRIPTION OF LINKED DATASET

\begin{tabular}{r|r|l|r|r|r}
\hline \hline Year & Yearbook & RICF & $\begin{array}{r}\text { Board Dataset } \\
\text { \%Population) }\end{array}$ & $\begin{array}{r}\text { \#Board Mbr } \\
\text { (Turnover) }\end{array}$ & $\begin{array}{r}\text { \#Political elites } \\
\text { (Turnover) }\end{array}$ \\
\hline 2010 & 2,200 & 2,040 & 591 & 7,923 & 68 \\
& & & $(27.88 \%)$ & $(-)$ & $(-)$ \\
2011 & 2,614 & 2,430 & 2,287 & 27,589 & 141 \\
& & & $(90.68 \%)$ & $(74.36 \%)$ & $(55.32 \%)$ \\
2012 & 3,029 & 2,880 & 2,540 & 30,313 & 138 \\
2013 & 3,549 & 3,344 & $(85.97 \%)$ & $(31.60 \%)$ & $(25.36 \%)$ \\
& & & $(91.57 \%)$ & $(29.11 \%)$ & 156 \\
2014 & 4,117 & 4,233 & 3,577 & 35,515 & $(24 \%)$ \\
& & & $(85.68 \%)$ & $(21.53 \%)$ & $(11.56 \%)$ \\
2015 & 4,784 & 4,895 & 3,454 & 36,595 & 147 \\
& & & $(71.37 \%)$ & $(31.14 \%)$ & $(17.99 \%)$ \\
\hline \hline
\end{tabular}

Notes: The table suggests data from 2011-2015 are of good quality with respect to the consistency of turnover rate and board dataset completion. Yearbook $=2017$ China Statistical Yearbook by National Bureau of Statistics of China (2017); RICF = Research Infrastructure of Chinese Foundations by Ma et al. (2017); Mbr = Member. Population is calculated as the average number of foundations recorded by Yearbook and RICF (e.g., for 2010, $\left.27.88 \%=591 /\left(\frac{2200+2040}{2}\right) \cdot 100 \%\right)$.

Table $\mathrm{S1}$ presents the structure of the linked dataset for this study. If we take the year 2013 as an example, the table presents the following: the 2017 China Statistical Yearbook (National Bureau of Statistics of China 2017) shows that there are 3,549 foundations in China, the RICF records 3,344 foundations, and the average population is 3,446.5 (i.e., $\frac{3549+3344}{2}$ ) foundations. I have the board member information of 3,156 foundations, which accounts for $91.57 \%$ of the average population. There are 36,553 unique board members, and $29.11 \%$ of them are new 
Table S2: PANEL STRUCTURE OF DATASET BY YEARS SITTING ON BOARD AND HOLDING THE SAME POLITICAL AFFILIATION

\begin{tabular}{|c|c|c|c|c|c|c|c|}
\hline & & & Years on & foundatio & s' boards & & \\
\hline & & 1 & 2 & 3 & 4 & 5 & Total \\
\hline & 1 & 55 & 14 & 7 & 8 & 7 & 91 \\
\hline & & $(100 \%)$ & $(29.2 \%)$ & $(14.9 \%)$ & $(12.9 \%)$ & $(9.6 \%)$ & $(31.9 \%)$ \\
\hline & 2 & - & 34 & 7 & 15 & 13 & 69 \\
\hline the same & & & $(70.8 \%)$ & $(14.9 \%)$ & $(24.2 \%)$ & $(17.8 \%)$ & $(24.2 \%)$ \\
\hline nolitical & 3 & - & - & 33 & 6 & 11 & 50 \\
\hline poffiliation & & & & $(70.2 \%)$ & $(9.7 \%)$ & $(15.1 \%)$ & $(17.5 \%)$ \\
\hline while on board & 4 & - & - & - & 33 & 6 & 39 \\
\hline & & & & & $(53.2 \%)$ & $(8.2 \%)$ & $(13.7 \%)$ \\
\hline & 5 & - & - & - & - & 36 & 36 \\
\hline & & & & & & $(49.3 \%)$ & $(12.6 \%)$ \\
\hline & Total $^{*}$ & 55 & 48 & 47 & 62 & 73 & 285 \\
\hline & & $(19.3 \%)$ & $(16.8 \%)$ & $(16.5 \%)$ & $(21.8 \%)$ & $(25.6 \%)$ & $(100 \%)$ \\
\hline
\end{tabular}

Note: Nearly half the political elites did not change their political or governmental affiliations while serving on foundations' boards. The table shows the counts of political elites by the years they stayed on foundations' boards and held the same political affiliation. For example, a government official stayed on a foundation's board for 5 years, was CCP for the first two years, PC for the second two years, and CYL for the last year, in which case she generates two counts for the 5-year-stay and 2-year-hold category, and one count for the 5-year-stay and 1-year-hold category. ${ }^{*}$ Percentages are by row, all other percentages are by column.

additions. There are 150 foundation trustees who also are political leaders, and $24 \%$ of them are new additions.

Figure $\mathrm{S} 1$ and Table $\mathrm{S} 2$ present more details on the dataset's structure. As the figure shows, the within-category variations are small, but turnover rates are large. The table shows that nearly half of the political elites did not change their political or governmental affiliations while serving on foundations' boards and that the observations are distributed fairly evenly with respect to the amount of time the political elites remained on a board and held the same position. In general, the analysis of the data structure suggests that, although the dataset is a panel, a fixed- or random-effect regression is not appropriate if we use the original position categories (e.g., the $\mathrm{CCP}$ and $\mathrm{CYL}$ ) as independent variables. 
Figure S1: PANEL STRUCTURE OF THE DATASET

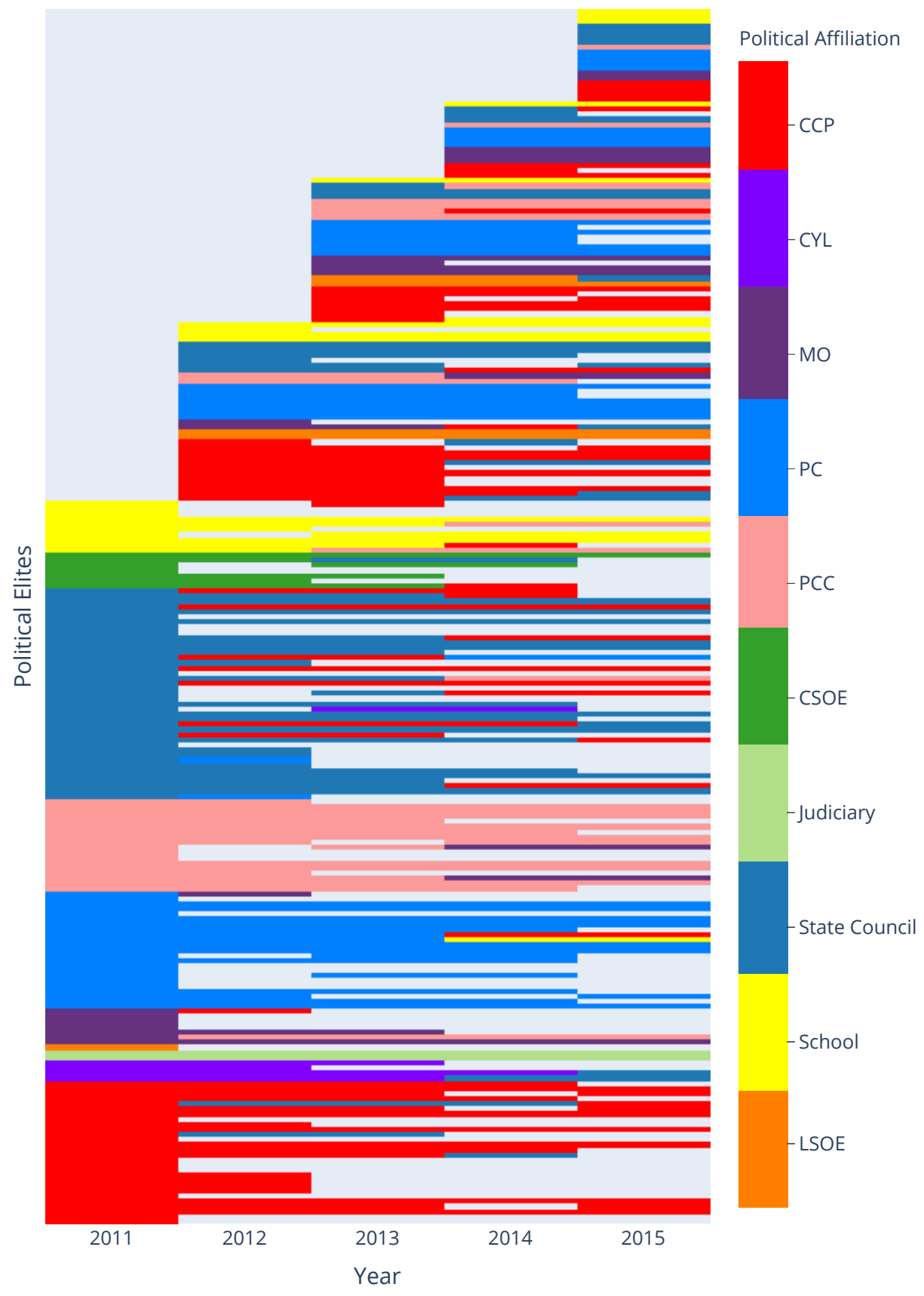

Notes: Each line on the Y-axis represents a political elite. As the figure shows, within-category variations are small, but turnover rates are high. $\mathrm{CCP}=$ Chinese Communist Party; $\mathrm{CYL}=$ Communist Youth League; $\mathrm{MO}=$ Mass Organization $; \mathrm{PC}=$ People's Congress; $\mathrm{PCC}=$ Political Consultative Conference; $\mathrm{CSOE}=$ Central state-owned enterprise; $\mathrm{LSOE}=$ Local state-owned enterprise. 


\section{Data Validation}

I validated the linked dataset's quality manually based on two considerations: disambiguating people and identifying political or governmental backgrounds. By manually checking five 50-observation bootstrap samples, the precision of identifying records with the same name, gender, and birth year as belonging to the same person is $83.2 \%$ and that of identifying political or governmental background is $77.2 \%$. Existing network studies rarely report these numbers of accuracy, so it is difficult to make comparisons. But I checked the misidentified records and found that they tended to be for less known and inactive individuals. Therefore, these misidentified records should generate limited influence on the analysis because these people tend to be isolated individuals who will not appear in the networks I am studying anyway. I used the records from 2011 to 2015 in the final analysis because they are more consistent and are of higher quality with respect to sample size and turnover rates (Table S1). The turnover rate for 2012 is the highest, suggesting that the political system had already begun to prearrange some postings before the year of a presidential change (i.e., 2013). There are flaws in the dataset, yet I made the utmost effort to minimize their impact.

\section{Qualitative Member Checking of Findings}

Following the member checking procedures described earlier, I conducted a series of interviews and focus groups. Table $\mathrm{S} 3$ lists the key informants and activities. The fieldwork generally confirmed the findings, and two cases are worth highlighting.

I interviewed a key informant who is a faculty member at the Central School of Communist Youth League (CSCYL). The CSCYL is the highest research and educational center of the CYL system that was established in 1948 to train CYL cadres and students. The informant agreed that CYL cadres are required to "keep grassroots," but he is confused by the finding that CYL leaders are the most connected political elites in the civil society network because Xi has criticized them as "being out of touch with the people." 
Table S3: KEY INFORMANTS AND FIELDWORK ACTIVITIES

\begin{tabular}{|c|c|c|}
\hline Date & ID & Informant / Activity Background \\
\hline 2019/05 & 1 & $\begin{array}{l}\text { Current faculty member of a university affiliated } \\
\text { think-tank. }\end{array}$ \\
\hline 2019/06 & 2 & $\begin{array}{l}\text { Current faculty member of a university affiliated } \\
\text { think-tank. }\end{array}$ \\
\hline 2019/06 & 3 & $\begin{array}{l}\text { Current faculty member of a university affiliated } \\
\text { think-tank. }\end{array}$ \\
\hline 2019/06 & 4 & $\begin{array}{l}\text { Presentation and focus group in a prestigious } \\
\text { university in Beijing, group size } 30 \text { people, audience } \\
\text { mainly from universities and think-tanks. }\end{array}$ \\
\hline 2019/07 & 5 & $\begin{array}{l}\text { Current faculty member of a prestigious university in } \\
\text { Beijing. }\end{array}$ \\
\hline 2019/07 & 6 & $\begin{array}{l}\text { Former cadre in the Party School of the Central } \\
\text { Committee of the Communist Party. }\end{array}$ \\
\hline 2019/07 & 5 & $\begin{array}{l}\text { Current faculty member of a prestigious university in } \\
\text { Beijing. }\end{array}$ \\
\hline 2019/07 & 7 & $\begin{array}{l}\text { Presentation and focus group in a prestigious } \\
\text { university in Beijing, group size } 15 \text { people, audience } \\
\text { mainly from the Party and Youth League's cadre } \\
\text { education system. }\end{array}$ \\
\hline 2019/08 & 8 & $\begin{array}{l}\text { Current faculty member of the Central School of } \\
\text { Communist Youth League. }\end{array}$ \\
\hline 2019/08 & 7 & $\begin{array}{l}\text { Former cadre in the Party School of the Central } \\
\text { Committee of the Communist Party. }\end{array}$ \\
\hline
\end{tabular}

The CSCYL faculty member concurred with my explanation that their perception of Xi's critiques and the results do not actually conflict. Being a CYL cadre can help an individual obtain a substantial "age advantage" later in his political career. Moreover, as this paper finds, cadres with previous CYL experience were significantly favored in the political network during Hu's presidency. These circumstances do not mean that "the current CYL cadres have been out of touch with the people" but instead may encourage "political opportunism"- this is what the CCP Central Committee fears (Kou and Tsai 2014).

I also interviewed another key informant who was a cadre at the Party School of the Central Committee of the Communist Party (also known as the Central Party School). The Central Party School is the highest research and educational center of the CCP system and was established in 
1933 to train future and incumbent CCP officials. He confirmed the results for the CYL, MO, CSOE, and School leaders. He particularly emphasized that intellectuals (i.e., the School category), especially political science scholars, began to assume more important roles under Xi's administration (e.g., Wang Huning, one of the CCP's top leaders and an influential political theorist). 


\section{Online Supplementary Material: Additional Tables and Figures}

Table S4: LEADING POSITIONS (I.E., CADRES) IN CHINA's CIVIL SERVICE SYSTEM

\begin{tabular}{|c|c|c|}
\hline Rank & Name & Example Positions \\
\hline \multicolumn{3}{|c|}{ National } \\
\hline 1 & $\begin{array}{r}\text { State Leader } \\
\text { (guojiaji zhengzhi) }\end{array}$ & $\begin{array}{l}\text { General Secretary of the Communist Party of China, } \\
\text { Premier of the State Council }\end{array}$ \\
\hline 2 & $\begin{array}{r}\text { State Deputy } \\
\text { (guojiaji fuzhi) }\end{array}$ & $\begin{array}{l}\text { Members of the Politburo of the Communist Party of } \\
\text { China, Vice Chair of the Political Consultative Con- } \\
\text { ference }\end{array}$ \\
\hline \multicolumn{3}{|c|}{$\overline{N a t i o n a l}$ or Provincial $\bar{l}$} \\
\hline 3 & $\begin{array}{r}\text { Province/Ministry Head } \\
\text { (shengbuji zhengzhi) }\end{array}$ & $\begin{array}{l}\text { First Secretary of the Communist Youth League, } \\
\text { Chair of national mass organizations (e.g., All-China } \\
\text { Federation of Trade Unions), Chair of a Provincial- } \\
\text { level People's Congress }\end{array}$ \\
\hline 4 & $\begin{array}{r}\text { Province/Ministry Deputy } \\
\text { (shengbuji fuzhi) }\end{array}$ & $\begin{array}{l}\text { Deputy Secretary of Party Committees of Provinces, } \\
\text { Vice Chair of a Provincial-level People's Congress, } \\
\text { Presidents of key state universities (e.g., Peking Uni- } \\
\text { versity) }\end{array}$ \\
\hline \multicolumn{3}{|c|}{$\bar{P}$ rovincial or $\bar{M}$ Mnicipal $\bar{l}$} \\
\hline 5 & $\begin{array}{r}\text { Bureau/Department Head } \\
\text { (tingjuji zhengzhi) }\end{array}$ & $\begin{array}{l}\text { Party Secretary of prefecture-level cities, President of } \\
\text { provincial universities, Chair of People's Congress of } \\
\text { prefecture-level cities }\end{array}$ \\
\hline 6 & $\begin{array}{r}\text { Bureau/Department Deputy } \\
\text { (tingjuji fuzhi) }\end{array}$ & $\begin{array}{l}\text { Deputy Party Secretary of Prefecture-level cities, } \\
\text { Deputy Chairs of provincial mass organizations (e.g., } \\
\text { All-China Women's Federation) }\end{array}$ \\
\hline \multicolumn{3}{|c|}{ County } \\
\hline 7 & $\begin{array}{r}\text { Division/County Head } \\
\text { (xianchuji zhengzhi) }\end{array}$ & $\begin{array}{l}\text { Party Secretary of counties, Party Secretary of dis- } \\
\text { tricts of prefecture-level cities, Chair of County-level } \\
\text { People's Political Consultative Conference }\end{array}$ \\
\hline 8 & $\begin{array}{l}\text { Division/County Deputy } \\
\text { (xianchuji fuzhi) }\end{array}$ & $\begin{array}{l}\text { Members of county-level Party Standing Committee, } \\
\text { Vice Mayor of counties }\end{array}$ \\
\hline \multicolumn{3}{|c|}{ Township } \\
\hline 9 & $\begin{array}{r}\text { Section/Township Head } \\
\text { (xiangkeji zhengzhi) }\end{array}$ & $\begin{array}{l}\text { Party Secretary of towns, Chair of township-level } \\
\text { People's Political Consultative Conference }\end{array}$ \\
\hline 10 & $\begin{array}{r}\text { Section/Township Deputy } \\
\text { (xiangkeji fuzhi) }\end{array}$ & $\begin{array}{l}\text { Deputy Heads of county-level party or government } \\
\text { organizations }\end{array}$ \\
\hline
\end{tabular}

Source: PRC National People's Congress (2005, Article 16), Kou and Tsai (2014, 157), and Chan and Li (2007, 393). 
Table S5: BRIDGING CIVIL SOCIETY AND POLITY: DifFERENTIATED EMBEDDEDNESS OF CHINESE POLITICAL ELITES

\begin{tabular}{|c|c|c|c|}
\hline & & $\begin{array}{l}\text { Civil society embeddedness } \\
\text { (horizontal connection) }\end{array}$ & $\begin{array}{l}\text { Political embeddedness } \\
\text { (vertical connection) }\end{array}$ \\
\hline \multirow[b]{2}{*}{$\begin{array}{l}\text { Embeddedness } \\
\text { of political elites }\end{array}$} & Strong & $\begin{array}{c}\text { CYL } \\
\text { (excellent state-agents for } \\
\text { mobilizing civic power) }\end{array}$ & $\begin{array}{l}\text { MO, School, State Council } \\
\text { (excellent access points } \\
\text { to political power) }\end{array}$ \\
\hline & Weak & $\begin{array}{c}\text { LSOE, CSOE } \\
\text { Judiciary, State Council } \\
\text { (marginalized state-agents } \\
\text { in civil society) }\end{array}$ & $\begin{array}{c}\text { CYL, CSOE } \\
\text { (ineffective access points } \\
\text { to political power) }\end{array}$ \\
\hline
\end{tabular}

Notes: $\mathrm{CYL}=$ Communist Youth League; $\mathrm{MO}=$ Mass Organization; $\mathrm{PC}=$ People's Congress; $\mathrm{PCC}=$ Political Consultative Conference; $\mathrm{CSOE}=$ Central state-owned enterprise; LSOE $=$ Local state-owned enterprise. 
Table S6: PATterns of LinkAGe Between Chinese POLITICAL Elites

\begin{tabular}{r|r|r|r|r|r}
\hline \hline Linkage & 2011 & 2012 & 2013 & 2014 & 2015 \\
\hline State Council-CCP & $27 \%$ & $25 \%$ & $15 \%$ & $21 \%$ & $21 \%$ \\
& $(21)$ & $(20)$ & $(6.0)$ & $(6.0)$ & $(8.0)$ \\
State Council & $13 \%$ & $11 \%$ & $12 \%$ & - & - \\
& $(10)$ & $(9.0)$ & 5.0 & & \\
PC-State Council & $10 \%$ & - & - & - & - \\
& $(8.0)$ & & & & \\
CCP & - & $10 \%$ & - & - & - \\
& & $(8.0)$ & & & \\
PC-CCP & - & $13 \%$ & - & - & - \\
& & $(10)$ & & & \\
PCC-State Council & - & - & $15 \%$ & $10 \%$ & - \\
& & & $(6.0)$ & $(3.0)$ & \\
PCC-CCP & - & - & - & $17 \%$ & $10 \%$ \\
& & & & $(5.0)$ & $(4.0)$ \\
\hline Cross category & $71 \%$ & $72 \%$ & $76 \%$ & $86 \%$ & $85 \%$ \\
& $(56)$ & $(57)$ & $(31)$ & $(25)$ & $(33)$ \\
\hline \hline
\end{tabular}

Notes: Showing links above $10 \%$ of total connections. Raw counts are in parentheses. $\mathrm{CCP}=$ Chinese Communist Party; PC $=$ People's Congress; $\mathrm{PCC}=$ Political Consultative Conference. 
Table S7: Robustness CHeck: Excluding All-China Women's Federation Cases

\begin{tabular}{|c|c|c|c|c|}
\hline & \multicolumn{2}{|c|}{ Nonprofit Embeddedness } & \multicolumn{2}{|c|}{ Political Embeddedness } \\
\hline & $H u$ & $X i$ & $H u$ & $X i$ \\
\hline \multicolumn{5}{|l|}{ Political Affiliation } \\
\hline \multirow[t]{2}{*}{$\mathrm{CCP}$} & -0.044 & -0.0053 & 0.24 & 0.046 \\
\hline & $(0.13)$ & $(0.090)$ & $(0.24)$ & $(0.060)$ \\
\hline \multirow[t]{2}{*}{ CYL } & $1.1^{*}$ & $1.2 * * *$ & -0.31 & $-0.21 * *$ \\
\hline & $(0.67)$ & $(0.40)$ & $(0.27)$ & $(0.11)$ \\
\hline \multirow[t]{2}{*}{ CYL Exp. } & 0.12 & 0.16 & $0.44 * *$ & 0.089 \\
\hline & $(0.18)$ & $(0.10)$ & $(0.19)$ & $(0.056)$ \\
\hline \multirow[t]{2}{*}{ Judicial } & 0.026 & $-0.12 *$ & -0.62 & 0.11 \\
\hline & $(0.17)$ & $(0.071)$ & $(0.53)$ & $(0.16)$ \\
\hline \multirow[t]{2}{*}{ LSOE } & -0.12 & $-0.16^{* *}$ & 0.17 & 0.10 \\
\hline & $(0.11)$ & $(0.075)$ & $(0.25)$ & $(0.12)$ \\
\hline \multirow[t]{2}{*}{ MO } & 0.090 & -0.072 & 0.25 & $0.28 * *$ \\
\hline & $(0.27)$ & $(0.11)$ & $(0.36)$ & $(0.12)$ \\
\hline \multirow[t]{2}{*}{ PCC } & 0.043 & -0.061 & -0.25 & 0.0046 \\
\hline & $(0.091)$ & $(0.074)$ & $(0.21)$ & $(0.074)$ \\
\hline \multirow[t]{2}{*}{$\mathrm{SC}$} & 0.12 & -0.10 & -0.10 & 0.031 \\
\hline & $(0.17)$ & $(0.079)$ & $(0.23)$ & $(0.056)$ \\
\hline \multirow[t]{2}{*}{ CSOE } & 0.085 & $-0.22 * *$ & 0.082 & $-0.23 * *$ \\
\hline & $(0.20)$ & $(0.11)$ & $(0.24)$ & $(0.12)$ \\
\hline \multirow[t]{2}{*}{ School } & 0.098 & 0.19 & -0.27 & $0.16^{*}$ \\
\hline & $(0.14)$ & $(0.14)$ & $(0.23)$ & $(0.088)$ \\
\hline \multicolumn{5}{|l|}{ Controls } \\
\hline \multirow[t]{2}{*}{ Male } & 0.024 & -0.16 & -0.31 & $-0.25 * * *$ \\
\hline & $(0.13)$ & $(0.14)$ & $(0.22)$ & (0.097) \\
\hline \multirow[t]{2}{*}{ Education } & 0.023 & -0.036 & -0.041 & 0.016 \\
\hline & $(0.025)$ & $(0.023)$ & $(0.063)$ & $(0.018)$ \\
\hline \multirow[t]{2}{*}{ Cadre rank } & 0.0063 & -0.011 & -0.045 & -0.014 \\
\hline & $(0.022)$ & $(0.011)$ & $(0.031)$ & $(0.011)$ \\
\hline \multirow[t]{2}{*}{ Age } & -0.056 & $-0.079 * *$ & -0.014 & -0.026 \\
\hline & $(0.049)$ & $(0.031)$ & $(0.070)$ & $(0.027)$ \\
\hline \multirow[t]{2}{*}{ Board size } & $0.73 * * *$ & $0.78 * * *$ & $0.099 * *$ & $0.10 * * *$ \\
\hline & $(0.027)$ & $(0.023)$ & $(0.050)$ & (0.019) \\
\hline \multirow[t]{2}{*}{ Embed. diversity } & $0.15 * * *$ & 0.029 & $-0.99 * * *$ & $-0.44 * * *$ \\
\hline & $(0.050)$ & $(0.032)$ & $(0.096)$ & $(0.029)$ \\
\hline \#Observations & 272 & 426 & 272 & 426 \\
\hline Adj. $R^{2}$ & 0.52 & 0.71 & 0.57 & 0.57 \\
\hline
\end{tabular}

Notes: Dependent variable $=$ Network degree. $\mathrm{PC}$ is the base group for political affiliation . Network degree, age, board size, and embeddedness diversity are transformed to $z$-scores. Bootstrap standard errors are in parentheses (Snijders and Borgatti 1999). $\chi^{2}$ column shows the Wald test results. $\mathrm{CCP}=$ Chinese Communist Party; $\mathrm{CYL}=$ Communist Youth League; CYL Exp. $=$ Cadres with previous CYL work experience; $\mathrm{MO}=$ Mass Organization; $\mathrm{PC}=$ People's Congress; $\mathrm{PCC}=$ Political Consultative Conference; $\mathrm{CSOE}=$ Central state-owned enterprise; LSOE $=$ Local state-owned enterprise. ${ }^{*} p<.1,{ }^{* *} p<.05,{ }^{* * *} p<.01$, two-tailed tests. 
Figure S2: A SAMPLE OF LINKED DATASET

\begin{tabular}{|c|c|c|c|c|c|c|}
\hline $\begin{array}{l}\text { Foundation } \\
\text { ID }\end{array}$ & Year & Name & Gender & Birth Year & Position & \\
\hline 54 & 2011 & XKJ & $M$ & 1973 & \multicolumn{2}{|c|}{ Morgan Stanley Huaxin Securities } \\
\hline 67 & 2015 & XKJ & $M$ & 1973 & \multicolumn{2}{|c|}{ Shanghai Municipal Investment Gr } \\
\hline 67 & 2014 & XKJ & M & 1973 & \multicolumn{2}{|c|}{ Shanghai Tower Construction \& De } \\
\hline 67 & 2013 & XKJ & M & 1973 & \multicolumn{2}{|c|}{ Morgan Stanley Huaxin Securities } \\
\hline 67 & 2012 & XKJ & M & 1973 & \multicolumn{2}{|c|}{ Morgan Stanley Huaxin Securities } \\
\hline 67 & 2011 & XKJ & $M$ & 1973 & \multicolumn{2}{|c|}{ Morgan Stanley Huaxin Securities C } \\
\hline 138 & 2014 & XKJ & M & 1973 & \multicolumn{2}{|c|}{ Shanghai Tower Construction \& De } \\
\hline 138 & 2013 & XKJ & M & 1973 & \multicolumn{2}{|c|}{ Morgan Stanley Huaxin Securities C } \\
\hline 138 & 2012 & XKJ & $M$ & 1973 & \multicolumn{2}{|c|}{ Morgan Stanley Huaxin Securities C } \\
\hline 138 & 2011 & XKJ & $M$ & 1973 & \multicolumn{2}{|c|}{ Morgan Stanley Huaxin Securities C } \\
\hline 250 & 2013 & CJS & M & 1956 & \multicolumn{2}{|c|}{ Federation of Social Science Assoxi } \\
\hline 250 & 2012 & CJS & M & 1956 & \multicolumn{2}{|c|}{ Federation of Social Science Assoxi } \\
\hline 250 & 2011 & CJS & M & 1956 & \multicolumn{2}{|c|}{ Ministry/ Department/Bureau of $\mathrm{W}$} \\
\hline 250 & 2010 & CJS & M & 1956 & State Council & \\
\hline 1387 & 2012 & CJS & M & 1956 & \multicolumn{2}{|c|}{ Federation of Social Science Assoxi } \\
\hline 1387 & 2013 & CJS & M & 1956 & \multicolumn{2}{|c|}{ Federation of Social Science Associi } \\
\hline 1387 & 2014 & CJS & $M$ & 1956 & \multicolumn{2}{|c|}{ Work Committee for Departments } \\
\hline 1387 & 2015 & CJS & M & 1956 & \multicolumn{2}{|c|}{ Work Committee for Departments } \\
\hline 253 & 2015 & LXM & M & 1951 & \multicolumn{2}{|c|}{ Politburo / Standing Committee, Pc } \\
\hline 253 & 2013 & LXM & $M$ & 1951 & \multicolumn{2}{|c|}{ Politburo / Standing Committee, Pc } \\
\hline 253 & 2012 & LXM & M & 1951 & \multicolumn{2}{|c|}{ Politburo / Standing Committee, Pc } \\
\hline 253 & 2011 & LXM & M & 1951 & \multicolumn{2}{|c|}{ Major Projects Construction Headq } \\
\hline 253 & 2010 & LXM & $\mathrm{M}$ & 1951 & \multicolumn{2}{|c|}{ Major Projects Construction Headq } \\
\hline 554 & 2015 & LXM & M & 1951 & \multicolumn{2}{|c|}{ Politburo / Standing Committee } \\
\hline 554 & 2014 & LXM & $M$ & 1951 & \multicolumn{2}{|c|}{ Politburo / Standing Committee } \\
\hline 554 & 2013 & LXM & $M$ & 1951 & \multicolumn{2}{|c|}{ Politburo / Standing Committee } \\
\hline
\end{tabular}

Notes: The final linked dataset of Ma et al. (2017) and Jiang (2018) can track a political elite's foundation membership and political position in a given year. For example, the political elite CJS were on two foundations' boards (i.e., Foundation ID 250 and 1387) between 2010 and 2015, and he changed his primary position four times during the same time period. 


\section{References}

Chan, Hon S., and Suizhou Edward Li. 2007. "Civil Service Law in the People's Republic of China: A Return to Cadre Personnel Management" [in en]. 00116, Public Administration Review 67 (3): 383-398. Accessed January 16, 2019. https://doi.org/10.1111/j.1540-6210.2007.00722.x.

Jiang, Junyan. 2018. "Making Bureaucracy Work: Patronage Networks, Performance Incentives, and Economic Development in China" [in en]. 00005, American Journal of Political Science 62 (4): 982-999. Accessed February 18, 2019. https://doi.org/10.1111/ajps.12394.

Kou, Chien-wen, and Wen-Hsuan Tsai. 2014. ““"Sprinting with Small Steps” Towards Promotion: Solutions for the Age Dilemma in the CCP Cadre Appointment System." 00051, The China Journal 71:153-171. Accessed December 15, 2018. https://doi.org/10.1086/674558.

Ma, Ji, Qun Wang, Chao Dong, and Huafang Li. 2017. "The research infrastructure of Chinese foundations, a database for Chinese civil society studies" [in en]. 00023, Scientific Data 4:sdata201794. Accessed July 29, 2017. https://doi.org/10.1038/sdata.2017.94.

National Bureau of Statistics of China. 2017. China Statistical Yearbook. 00004. China Statistical Yearbook. Accessed December 26, 2016.

PRC National People's Congress. 2005. Law of the People's Republic of China on Public Servants. 00000. Accessed January 16, 2019. http://www.npc.gov.cn/englishnpc/Law/2007-12/13/content_1384101.htm.

Snijders, Tom AB, and Stephen P. Borgatti. 1999. "Non-parametric standard errors and tests for network statistics.” 00157, Connections 22 (2): 161-170. Accessed November 30, 2015. http://citeseerx.ist.psu.edu/viewdoc/download?doi=10.1.1.8.3077\&rep=rep1\&type=pdf. 